\title{
Emission-dominated gas exchange of elemental mercury vapor over natural surfaces in China
}

\author{
Xun Wang ${ }^{1,2}$, Che-Jen Lin ${ }^{1,3,4}$, Wei Yuan ${ }^{1,2}$, Jonas Sommar ${ }^{1}$, Wei Zhu ${ }^{1}$, and Xinbin Feng ${ }^{1}$ \\ ${ }^{1}$ State Key Laboratory of Environmental Geochemistry, Institute of Geochemistry, Chinese Academy of Sciences, \\ Guiyang, China \\ ${ }^{2}$ University of Chinese Academy of Sciences, Beijing, China \\ ${ }^{3}$ Center for Advances in Water and Air Quality, Lamar University, Beaumont, TX, USA \\ ${ }^{4}$ Department of Civil and Environmental Engineering, Lamar University, Beaumont, TX, USA
}

Correspondence to: Xinbin Feng (fengxinbin@vip.skleg.cn) and Che-Jen Lin (jerry.lin@lamar.edu)

Received: 11 April 2016 - Published in Atmos. Chem. Phys. Discuss.: 11 May 2016

Revised: 7 August 2016 - Accepted: 28 August 2016 - Published: 8 September 2016

\begin{abstract}
Mercury (Hg) emission from natural surfaces plays an important role in global $\mathrm{Hg}$ cycling. The present estimate of global natural emission has large uncertainty and remains unverified against field data, particularly for terrestrial surfaces. In this study, a mechanistic model is developed for estimating the emission of elemental mercury vapor $\left(\mathrm{Hg}^{0}\right)$ from natural surfaces in China. The development implements recent advancements in the understanding of airsoil and air-foliage exchange of $\mathrm{Hg}^{0}$ and redox chemistry in soil and on surfaces, incorporates the effects of soil characteristics and land use changes by agricultural activities, and is examined through a systematic set of sensitivity simulations. Using the model, the net exchange of $\mathrm{Hg}^{0}$ between the atmosphere and natural surfaces of mainland China is estimated to be $465.1 \mathrm{Mg} \mathrm{yr}^{-1}$, including $565.5 \mathrm{Mg} \mathrm{yr}^{-1}$ from soil surfaces, $9.0 \mathrm{Mg} \mathrm{yr}^{-1}$ from water bodies, and $-100.4 \mathrm{Mg} \mathrm{yr}^{-1}$ from vegetation. The air-surface exchange is strongly dependent on the land use and meteorology, with $9 \%$ of net emission from forest ecosystems; $50 \%$ from shrubland, savanna, and grassland; $33 \%$ from cropland; and $8 \%$ from other land uses. Given the large agricultural land area in China, farming activities play an important role on the air-surface exchange over farmland. Particularly, rice field shift from a net sink (3.3 Mg uptake) during April-October (rice planting) to a net source when the farmland is not flooded (November-March). Summing up the emission from each land use, more than half of the total emission occurs in summer $(51 \%)$, followed by spring $(28 \%)$, autumn $(13 \%)$, and winter $(8 \%)$. Model verification is accomplished using observational data of air-
\end{abstract}

soil/air-water fluxes and $\mathrm{Hg}$ deposition through litterfall for forest ecosystems in China and Monte Carlo simulations. In contrast to the earlier estimate by Shetty et al. (2008) that reported large emission from vegetative surfaces using an evapotranspiration approach, the estimate in this study shows natural emissions are primarily from grassland and dry cropland. Such an emission pattern may alter the current understanding of $\mathrm{Hg}$ emission outflow from China as reported by Lin et al. (2010b) because a substantial natural $\mathrm{Hg}$ emission occurs in West China.

\section{Introduction}

Accurate inventories of mercury $(\mathrm{Hg})$ emission are the foundation for assessing $\mathrm{Hg}$ global biogeochemical cycling (Selin, 2009; Streets et al., 2009, 2011). The inventories of $\mathrm{Hg}$ emission include the emission from anthropogenic sources and the so-called "natural" emission that includes the primary natural release (i.e., from geogenic activities) and the re-emission of legacy $\mathrm{Hg}$ stored in the terrestrial and water surfaces. $\mathrm{Hg}$ emission from anthropogenic sources has been quantified and updated with reasonable consistency since the 1990s (Streets et al., 2009, 2011; Zhang et al., 2015; Zhang et al., 2016). In particular, the inclusion of the release from commercial products and modifications of $\mathrm{Hg}$ emission speciation profiles corresponding to the implementation and upgrade of air pollution control technologies have substantially reduced the uncertainty of anthropogenic $\mathrm{Hg}$ emission esti- 
mates (Horowitz et al., 2014; Zhang et al., 2016). In contrast, estimates of natural $\mathrm{Hg}$ emission are poorly constrained and have large uncertainties $\left( \pm 2000 \mathrm{Mg} \mathrm{yr}^{-1}\right)$, limiting the understanding of global and regional $\mathrm{Hg}$ cycling budgets (Pirrone et al., 2010; X. Wang et al., 2014; Song et al., 2015). In light of the control of anthropogenic $\mathrm{Hg}$ emission by the legally binding Minamata Convention (Pacyna et al., 2016), a better quantification of natural $\mathrm{Hg}$ emission is critical in evaluating the effectiveness of policy actions (Selin, 2009; Pirrone et al., 2010; Song et al., 2015).

One of the greatest challenges in predicting natural $\mathrm{Hg}$ emissions is the limited understanding in the air-surface $\mathrm{Hg}^{0}$ exchange processes among multiple environmental compartments, such as those in a terrestrial vegetative ecosystem. Estimates from regression-based models derived from the correlations between $\mathrm{Hg}$ flux and environmental parameters (temperature, solar radiation, etc.) may not be representative (Xu et al., 1999; Bash et al., 2004; Lin et al., 2005; Gbor et al., 2006; Shetty et al., 2008; Selin et al., 2008; Smith-Downey et al., 2010) because the relationships between measured fluxed and environmental factors are based on limited field data that are site specific, which cannot account for the heterogeneity in soil properties and vegetative coverages. Although the bidirectional resistance schemes describing $\mathrm{Hg}^{0}$ gas exchange may be appropriate (Bash, 2010; X. Wang et al., 2014; Wright and Zhang, 2015), they are limited by the availability of required soil property data and other physicochemical parameters such as $\mathrm{Hg}^{\mathrm{II}}$ reduction kinetics and characteristics of interfacial exchanges (Bash, 2010; X. Wang et al., 2014), leading to inconsistences between simulated and measured fluxes. Other challenges, including acquiring and integrating the meteorology, land use, and soil property data ( $\mathrm{Hg}$ content and other characteristics) in a model domain covering China, call for further model development to estimate natural $\mathrm{Hg}$ emission (X. Wang et al., 2014).

Recent advances in the understanding of $\mathrm{Hg}^{\mathrm{II}}$ reduction provide new opportunities to build a more physically robust air-soil exchange scheme. These include constrained $10^{-11}$ to $10^{-10} \mathrm{~s}^{-1}$ pseudo-first-order rate constant of $\mathrm{Hg}^{\mathrm{II}}$ reduction in soil (Scholtz et al., 2003; Qureshi et al., 2011) and $0.2-1.0 \mathrm{~h}^{-1}$ rate constant in natural water (O'Driscoll et al., 2006; Qureshi et al., 2010). In these reactions, the UV band of actinic light has been shown to be the primary driver for $\mathrm{Hg}^{\mathrm{II}}$ photoreduction in soils and water bodies (Moore and Carpi, 2005; Si and Ariya, 2011), and the role of functional substructures (e.g., - $\mathrm{C}(\mathrm{O}) \mathrm{OH},-\mathrm{SH},-\mathrm{OH})$ of DOM (dissolved organic matter) in the reduction has been determined by kinetic studies using model compounds (He et al., 2012; $\mathrm{Si}$ and Ariya, 2011, 2015). The presence of dissolved $\mathrm{O}_{2}$ has been shown to inhibit most aqueous $\mathrm{Hg}^{\mathrm{II}}$ reduction but not the photoreduction of $\mathrm{Hg}^{\mathrm{II}}$ bound to R-SH ( $\mathrm{Si}$ and Ariya, 2011). In dry soil, the first-order rate constants of $\mathrm{Hg}^{\mathrm{II}}$ photoreduction are $0.007-0.028 \mathrm{~h}^{-1}$ for $\mathrm{HgCl}_{2}$ coated over sand and $0.003-0.006 \mathrm{~h}^{-1}$ for $\mathrm{Hg}^{\mathrm{II}}$ in a natural soil (Quinones and
Carpi, 2011). In the absence of light, $\mathrm{Hg}^{\mathrm{II}}$ reduction in soil is also observed at a rate of $0.001-0.002 \mathrm{~h}^{-1}$ at $293 \mathrm{~K}$ (Pannu, 2012).

Intercontinental transport of $\mathrm{Hg}$ emission in China has been suggested to enhance $\mathrm{Hg}$ deposition in North America (Jaffe et al., 2005; Strode et al., 2008; Lin et al., 2010b; Chen et al., 2014). However, the natural Hg emission inventory used in earlier modeling studies may not be representative. S. Wang et al. (2014) suggested the $\mathrm{Hg}$ emissions in China from natural and anthropogenic sources are comparable. Shetty et al. (2008) estimated the natural Hg emission in China to be $462 \mathrm{Mg} \mathrm{yr}^{-1}$ using an outdated model scheme, which was applied for assessing regional $\mathrm{Hg}$ budgets in Est Asia (Lin et al., 2010b; Zhu et al., 2015). The large uncertainty associated with the earlier estimate warrants a reassessment of these earlier modeling efforts. In addition, the data of soil $\mathrm{Hg}$ concentration used in Shetty et al. (2008) are more than 3 decades old and require updates to appropriately represent spatial distribution of soil $\mathrm{Hg}$ contents that have been modified due to the rapid industrial development and urbanization occurring in China since 1980s. This data deficiency has been addressed by the National Multi-Purpose Regional Geochemical Survey (NMPRGS) of China, which was completed in 2014 (Li et al., 2014). This database provides soil $\mathrm{Hg}$ content for the agricultural and industrialized regions at a resolution of $4 \mathrm{~km}$, which may substantially reduce uncertainty caused by data deficiency. In addition, the datasets of terrestrial flux in mainland China recently reported in the literature allow verification of model results and optimization of model schemes. These field data of $\mathrm{Hg}^{0}$ air-surface exchange in China document the flux characteristics over different land uses including urban-rural-remote differences and effects of crop rotation over agricultural lands (Fu et al., 2008, 2010, 2012, 2013a; Zhu et al., 2011; Zhu et al., 2013; Zhu et al., 2016; Sommar et al., 2013a, b, 2016a).

Given the scientific advancements and new data availability discussed above, this work develops a state-of-the-science mechanistic model for estimating the natural $\mathrm{Hg}$ emission in China. For the first time, the simulated natural emission flux is verified with field measurements over different land surfaces in a modeling effort. The spatial, temporal, and seasonal characteristics of the model-estimated emissions over soil, vegetative surface, and water are presented and compared to the earlier estimates performed by Shetty et al. (2008). The implications of the new estimate are discussed in terms of chemical transport of $\mathrm{Hg}$ emission in China and the need for a re-assessment of mercury emission outflow from China. 


\section{Methods}

\subsection{Model description}

Compared to the earlier mechanistic schemes (X. Wang et al., 2014; Bash, 2010; Scholtz et al., 2003; Zhang et al., 2012b), this model (1) builds a new scheme for estimating the airsoil flux based on the reduction pathways of reactive $\mathrm{Hg}$ in soil identified in the literature, (2) develops a scheme for the $\mathrm{Hg}$ flux exchange over rice paddy, which is an important land use feature in China, and (3) updates the scheme for the airsnow interface and chemical parameters for air-foliage flux (Table 1).

\subsubsection{Reduction of $\mathrm{Hg}^{\mathrm{II}}$ in soil}

Based on $\mathrm{Hg}^{\mathrm{II}}$ reduction mechanisms proposed in peerreviewed literature (Moore and Carpi, 2005; Quinones and Carpi, 2011; Si and Ariya, 2011; Pannu, 2012), a new model describing $\mathrm{Hg}^{0}$ formation from $\mathrm{Hg}^{\mathrm{II}}$ reduction in soil is developed using three reaction pathways: (1) photoreduction of $\mathrm{Hg}^{\mathrm{II}}$ in soil pore water $\left(\mathrm{Hg}_{1}^{0}\right)$, (2) photoreduction of $\mathrm{Hg}^{\mathrm{II}}$ associated with soil particles $\left(\mathrm{Hg}_{2}^{0}\right)$, and (3) $\mathrm{Hg}^{\mathrm{II}}$ reduction through nonphotochemical pathways $\left(\mathrm{Hg}_{3}^{0}\right)$. The production of $\mathrm{Hg}^{0}$ in surface soil is calculated as

$$
\begin{aligned}
\frac{\mathrm{dHg} g_{1}^{0}}{\mathrm{~d} t}=K_{1} \cdot \mathrm{Hg}_{\mathrm{s}, \mathrm{m}} \\
\frac{\mathrm{dHg}_{2}^{0}}{\mathrm{~d} t}=K_{2} \cdot \mathrm{Hg}_{\mathrm{p}, \mathrm{m}} \\
\frac{\mathrm{dHg}_{3}^{0}}{\mathrm{~d} t}=K_{3} \cdot \mathrm{Hg}_{\mathrm{t}, \mathrm{m}},
\end{aligned}
$$

where $K_{1}$ is the photoreduction rate constant of $\mathrm{Hg}^{\mathrm{II}}$ in soil pore water (a comprehensive parameter list with units is shown in Table 1), $K_{2}$ is the photoreduction rate constant of $\mathrm{Hg}^{\mathrm{II}}$ associated with soil particles, $K_{3}$ is the $\mathrm{Hg}^{\mathrm{II}}$ reduction rate constant in soil through nonphotochemical pathways, $\mathrm{Hg}_{\mathrm{s}, \mathrm{m}}$ is the $\mathrm{Hg}^{\mathrm{II}}$ pool in soil pore water, $\mathrm{Hg}_{\mathrm{p}, \mathrm{m}}$ is the labile $\mathrm{Hg}^{\mathrm{II}}$ pool available for reduction on soil particles, and $\mathrm{Hg}_{\mathrm{t}, \mathrm{m}}$ is the total reducible $\mathrm{Hg}^{\text {II }}$ pool in soil. Based on the Arrhenius equation, $K_{1}$ and $K_{2}$ are parameterized as a function of solar irradiance and soil temperature, and $K_{3}$ is parameterized as a function of soil temperature and soil moisture:

$$
\begin{aligned}
& K_{1}=k_{1} \cdot R \cdot \gamma \cdot e^{\frac{T-T_{f}}{T_{f}} \cdot \frac{E_{\mathrm{a}}}{T}} \\
& K_{2}=k_{2} \cdot R_{i} \cdot \gamma \cdot e^{\frac{T-T_{f}}{T_{f}} \cdot \frac{E_{\mathrm{a}}}{T}} \\
& K_{3}=k_{3} \cdot e^{\frac{T-T_{f}}{T_{f}} \cdot \frac{E_{\mathrm{a}}}{T}} \cdot e^{\frac{\theta-\theta_{f}}{\theta_{f}} \cdot \frac{E_{\mathrm{b}}}{\theta}},
\end{aligned}
$$

where $k_{1}$ and $k_{2}$ are the photoreduction rate constants at the reference soil temperature $\left(T_{f}\right.$; Table 1$) . k_{3}$ is the darkreduction rate constant at the reference soil temperature and soil moisture $\left(\theta_{f}\right.$; Table 1$) . R$ and $R_{i}$ are total solar irradiance in the soil profile and under the canopy, respectively. $\gamma$ is the ratio of UV over total solar irradiance. An empirical rule suggests that a $10^{\circ} \mathrm{C}$ temperature increase doubles the rates for chemical reactions near room temperature (Kissinger, 1957; Hood et al., 1975), which has been shown to be applicable to $\mathrm{Hg}^{\mathrm{II}}$ reduction in boreal soil (Pannu et al., 2014). In addition, $\mathrm{Hg}$ emission flux from soil substrate doubles at $\sim 25 \%$ increase of soil moisture content (Lin et al., 2010a). Based on these observations, Eqs. (4)-(6) can be simplified as

$$
\begin{aligned}
& K_{1}=k_{1} \cdot R \cdot \gamma \cdot 2^{\frac{T-T_{f}}{10}} \\
& K_{2}=k_{2} \cdot R_{i} \cdot \gamma \cdot 2^{\frac{T-T_{f}}{10}} \\
& K_{3}=k_{3} \cdot 2^{\frac{T-T_{f}}{10}} \cdot 2^{4 \cdot\left(\theta-\theta_{f}\right)} .
\end{aligned}
$$

$R$ and $R_{i}$ in Eqs. (7)-(8) are calculated based on the BeerLambert law:

$$
\begin{aligned}
& R_{i}=R_{0} \cdot e^{-K \cdot \mathrm{LAI}} \\
& R=R_{i} \cdot \int_{0}^{l} e^{-k_{r} \cdot l} \mathrm{~d} l,
\end{aligned}
$$

where $R_{0}$ is solar irradiance above the canopy, $K$ is the canopy light extinction coefficient, LAI is leaf area index, $k_{r}$ is the light extinction coefficient in soil, and $l$ is the depth of surface soil.

$\mathrm{Hg}_{\mathrm{s}, \mathrm{m}}, \mathrm{Hg}_{\mathrm{p}, \mathrm{m}}$, and $\mathrm{Hg}_{\mathrm{t}, \mathrm{m}}$ are calculated based on Lyon et al. (1997):

$$
\begin{aligned}
& \mathrm{Hg}_{\mathrm{s}, \mathrm{m}}=\frac{\left[\mathrm{Hg}_{\mathrm{t}}\right] \cdot \mathrm{BD}}{\theta+\mathrm{kd} \cdot \mathrm{BD}} \cdot V \cdot \theta \times 10^{6} \\
& \mathrm{Hg}_{\mathrm{p}, \mathrm{m}}=\frac{\left[\mathrm{Hg}_{\mathrm{t}}\right] \cdot \mathrm{BD} \cdot \mathrm{kd}}{\theta+\mathrm{kd} \cdot \mathrm{BD}} \cdot \mathrm{BD} \cdot V \cdot \varphi \\
& \mathrm{Hg}_{\mathrm{t}, \mathrm{m}}=\left[\mathrm{Hg}_{\mathrm{t}}\right] \cdot \mathrm{BD} \cdot V \cdot \varphi,
\end{aligned}
$$

where $\left[\mathrm{Hg}_{\mathrm{t}}\right]$ is the total $\mathrm{Hg}^{\mathrm{II}}$ concentration in soil, $\mathrm{BD}$ is the soil bulk density, $\theta$ is the soil moisture, $V$ is the soil volume, and $\varphi$ is the ratio of reducible $\mathrm{Hg}$ over total $\mathrm{Hg}$ in soil. $\mathrm{kd}$ is the soil-water partition coefficient and calculated following Lee et al. (2001) and Sauve et al. (2000):

$\log \mathrm{kd}=r \cdot \mathrm{pH}+s \cdot \log \left(1000 \cdot f_{\mathrm{oc}}\right)+t$,

where $f_{\text {oc }}$ is the fraction of organic carbon in surface soil. The values $r, s$, and $t$ are regression coefficients.

Following Obrist et al. (2014), we assume that the $\mathrm{Hg}^{0}$ emission from soil is controlled by diffusion after $\mathrm{Hg}^{\mathrm{II}}$ reduction. Basing on the Fick's first law, the observed air-soil flux exchange can be calculated as

$$
\begin{aligned}
& F_{\text {soil }}=\operatorname{Hg}_{1}^{0}+\operatorname{Hg}_{2}^{0}+\mathrm{Hg}_{3}^{0}-2 \cdot D_{\text {soil }} \frac{\mathrm{GEM}}{d} \Delta t \\
& D_{\text {soil }}=0.66 \cdot(\sigma-\theta) \cdot D_{0},
\end{aligned}
$$

where $D_{\text {soil }}$ and $D_{0}$ are the diffusivities of $\mathrm{Hg}^{0}$ vapor in soil and ambient air, GEM is the atmospheric $\mathrm{Hg}^{0}$ concentration, 
Table 1. Model variables, constants, and rate coefficients used in the model simulation.

\begin{tabular}{|c|c|c|c|}
\hline Term & Description & Values/units & References/sources \\
\hline $\mathrm{Hg}_{1}^{0}$ & $\mathrm{Hg}^{0}$ formed by photoreduction in solution & $n g m^{-2} h^{-1}$ & \\
\hline $\mathrm{Hg}_{2}$ & $\mathrm{Hg}^{0}$ formed by photoreduction in particles & $n g \mathrm{~m}^{-2} \mathrm{~h}^{-1}$ & \\
\hline $\mathrm{Hg}_{3}^{0}$ & $\mathrm{Hg}^{0}$ formed by the dark reduction in soil & $n g m^{-2} h^{-1}$ & \\
\hline$K_{1}$ & Photoreduction rate in soil solution & $s^{-1}$ & \\
\hline$K_{2}$ & Photoreduction rate constant in particles & $\mathrm{s}^{-1}$ & \\
\hline$K_{3}$ & Dark-reduction rate constant in soil & $\mathrm{s}^{-1}$ & \\
\hline $\mathrm{Hg}_{\mathrm{s}, \mathrm{m}}$ & $\mathrm{Hg}^{\mathrm{II}}$ pool in soil pore water & $n g m^{-2}$ & \\
\hline $\mathrm{Hg}_{\mathrm{p}, \mathrm{m}}$ & Reducible $\mathrm{Hg}^{\mathrm{II}}$ pool in soil particles & $n g \mathrm{~m}^{-2}$ & \\
\hline $\mathrm{Hg}_{\mathrm{t}, \mathrm{m}}$ & Total reducible $\mathrm{Hg}^{\mathrm{II}}$ pool in soil & $\mathrm{ng} \mathrm{m} \mathrm{m}^{-2}$ & \\
\hline$T$ & Temperature & $\mathrm{K}$ & WRF \\
\hline$\theta$ & Soil moisture & $\%$ & WRF \\
\hline$R$ & Total solar radiation & $\mathrm{W} \mathrm{m}^{-2}$ & WRF \\
\hline $\mathrm{BD}$ & Soil bulk density & $\mathrm{g} \mathrm{cm}^{-3}$ & Shangguan et al. (2013) \\
\hline LAI & Leaf area index & $\mathrm{m}^{2} \mathrm{~m}^{-2}$ & WRF (Yuan et al., 2011) \\
\hline$\left[\mathrm{Hg}_{\mathrm{t}}\right]$ & Total $\mathrm{Hg}^{\mathrm{II}}$ concentration in soil & $\operatorname{ng~g}^{-1}$ & \\
\hline$V$ & Soil volume & $\mathrm{m}^{3}$ & \\
\hline $\mathrm{kd}$ & Soil-water partition coefficient & $\mathrm{L} \mathrm{kg}^{-1}$ & \\
\hline GEM & Atmospheric $\mathrm{Hg}^{0}$ concentration & $\operatorname{ng~m}{ }^{-3}$ & Lin et al. (2010b) \\
\hline$\sigma$ & Soil porosity & $\%$ & Shangguan et al. (2013) \\
\hline$D_{\text {soil }}$ & $\mathrm{Hg}^{0}$ vapor diffusion coefficient in soil & $\mathrm{m}^{2} \mathrm{~s}^{-1}$ & \\
\hline$D_{0}$ & $\mathrm{Hg}^{0}$ vapor diffusion coefficient in ambient air & $1.31 \times 10^{-5} \mathrm{~m}^{2} \mathrm{~s}^{-1}$ & Scholtz et al. (2003) \\
\hline$F_{\mathrm{cnp}}$ & The flux over canopy biomes & $\mathrm{ng} \mathrm{m}^{-2} \mathrm{~h}^{-1}$ & \\
\hline$\Delta t$ & Time duration & $\mathrm{s}$ & \\
\hline$R_{\mathrm{a}}$ & Aerodynamic resistance & $\mathrm{s} \mathrm{m}^{-1}$ & X. Wang et al. (2014); Zhang et al. (2012b) \\
\hline$R_{\mathrm{b}}$ & Quasi-laminar sublayer resistance & $\mathrm{s} \mathrm{m}^{-1}$ & X. Wang et al. (2014); Zhang et al. (2012b) \\
\hline$C_{\mathrm{atm}}$ & Atmospheric $\mathrm{Hg}$ concentration & $n g m^{-3}$ & X. Wang et al. (2014); Zhang et al. (2012b) \\
\hline$\chi_{\mathrm{cnp}}$ & The total compensation point & $n g m^{-3}$ & X. Wang et al. (2014); Zhang et al. (2012b) \\
\hline$\chi_{\mathrm{c}}$ & Cuticular interfaces compensation point & $n g m^{-3}$ & X. Wang et al. (2014); Zhang et al. (2012b) \\
\hline$\chi_{\mathrm{s}}$ & Stomatal interfaces compensation point & $n g m^{-3}$ & X. Wang et al. (2014); Zhang et al. (2012b) \\
\hline$\chi_{\mathrm{g}}$ & Soil interfaces compensation point & $n g m^{-3}$ & X. Wang et al. (2014); Zhang et al. (2012b) \\
\hline$R_{\mathrm{c}}$ & Cuticular resistance & $\mathrm{s} \mathrm{m}^{-1}$ & X. Wang et al. (2014); Zhang et al. (2012b) \\
\hline$R_{\mathrm{S}}$ & Stomatal resistance & $\mathrm{s} \mathrm{m}^{-1}$ & X. Wang et al. (2014); Zhang et al. (2012b) \\
\hline$R_{\mathrm{g}}$ & Soil diffusion resistance & $\mathrm{s} \mathrm{m}^{-1}$ & X. Wang et al. (2014); Zhang et al. (2012b) \\
\hline$R_{\mathrm{W}}$ & Water diffusion resistance & $\mathrm{s} \mathrm{m}^{-1}$ & X. Wang et al. (2014); Zhang et al. (2012b) \\
\hline$R_{\mathrm{g}\left(\mathrm{SO}_{2}\right)}$ & $\mathrm{SO}_{2}$ soil diffusion resistance & $\mathrm{s} \mathrm{m}^{-1}$ & X. Wang et al. (2014); Zhang et al. (2012b) \\
\hline$R_{\mathrm{g}\left(\mathrm{O}_{3}\right)}$ & $\mathrm{O}_{3}$ soil diffusion resistance & $\mathrm{s} \mathrm{m}^{-1}$ & X. Wang et al. (2014); Zhang et al. (2012b) \\
\hline$d$ & Light penetration into soil column & $2.00 \mathrm{~mm}$ & Hebert and Miller (1990) \\
\hline$\gamma$ & Ratio of UV radiation over total radiation & 0.08 & Moan (2001) \\
\hline$K$ & Canopy light extinction coefficient & 0.56 & Zhang et al. (2014) \\
\hline$k_{r}$ & Light extinction coefficient in soil & $3 \mathrm{~mm}^{-1}$ & Ciani et al. (2005) \\
\hline$k_{1}$ & Photoreduction rate constant in soil solution & $6.0 \times 10^{-9} \mathrm{~m}^{2} \mathrm{~W}^{-1} \mathrm{~s}^{-1}$ & Si and Ariya (2011) \\
\hline$k_{2}$ & Photoreduction rate constant in soil particles & $2.0 \times 10^{-3} \mathrm{~m}^{2} \mathrm{~W}^{-1} \mathrm{~h}^{-1}$ & Quinones and Carpi (2011) \\
\hline$k_{3}$ & Dark-reduction rate constant in soil & $1.0 \times 10^{-3} \mathrm{~h}^{-1}$ & Pannu (2012) \\
\hline$T_{\mathrm{f}}$ & Reference soil temperature & $32^{\circ} \mathrm{C}$ (Eq. 8), $20^{\circ} \mathrm{C}$ (Eqs. 7, 9) & Pannu (2012); Quinones and Carpi (2011) \\
\hline$\theta_{\mathrm{f}}$ & Reference soil moisture & $25 \%$ & Lin et al. (2010a) \\
\hline$r$ & Empirical value from regression & 0.52 & Lee et al. (2001); Sauve et al. (2000) \\
\hline$s$ & Empirical value from regression & 0.89 & Lee et al. (2001); Sauve et al. (2000) \\
\hline$t$ & Empirical value from regression & -0.71 & Lee et al. (2001); Sauve et al. (2000) \\
\hline$\varphi$ & Ratio of reducible $\mathrm{Hg}$ in soil & 0.003 (bare), 0.03 (others) & Pannu (2012) \\
\hline$\alpha_{\mathrm{Hg}^{0}}$ & Scaling factor of reactivity $\mathrm{Hg}$ & 0 & X. Wang et al. (2014) \\
\hline$\beta_{\mathrm{Hg}^{0}}$ & Scaling factor of reactivity $\mathrm{Hg}$ & 0.1 & X. Wang et al. (2014) \\
\hline $\mathrm{Hg}_{\mathrm{w}}^{2+}$ & $\mathrm{Hg}^{\mathrm{II}}$ concentration on leaf & $3 \mathrm{ng} \mathrm{m}^{-2}$ leaf & Laacouri et al. (2013) \\
\hline
\end{tabular}


and $\sigma$ is the soil porosity. Hence, during a time period $\Delta t$, the soil $\mathrm{Hg}^{0}$ vapor compensation point used in the bidirectional resistance model can be derived as

$\chi_{g}=\frac{\left(\mathrm{Hg}_{1}^{0}+\mathrm{Hg}_{2}^{0}+\mathrm{Hg}_{3}^{0}\right) \cdot d}{2 \cdot D_{\text {soil }} \cdot \Delta t}$.

\subsubsection{Updates for air-terrestrial exchanges}

Extending from the two categories (vegetated canopy and bare land) from our earlier work (X. Wang et al., 2014, the terrestrial system is divided into four categories: vegetated surface with unsaturated soil moisture (forest, grassland, shrubland, etc.), vegetated surface with saturated soil (i.e., rice paddy), barren or sparsely vegetated land, and snow/ice surface. The governing equation for calculating $\mathrm{Hg}^{0}$ airsurface exchange over vegetated surfaces is

$F_{\mathrm{cnp}}=\frac{\Delta t}{\left(R_{\mathrm{a}}+R_{\mathrm{b}}\right)}\left(\chi_{\mathrm{cnp}}-C_{\mathrm{atm}}\right)$,

where $R_{\mathrm{a}}$ is the aerodynamic resistance, $R_{\mathrm{b}}$ is the quasilaminar sublayer resistance, $C_{\text {atm }}$ is the atmospheric $\mathrm{Hg}$ concentration, and $\chi_{\mathrm{cnp}}$ is the overall compensation point. For the canopy biomes with unsaturated soil, $\chi_{\mathrm{cnp}}$ is parameterized as in X. Wang et al. (2014):

$\chi_{\text {cnp }}=\frac{\frac{\chi_{\mathrm{c}}}{R_{\mathrm{c}}}+\frac{\chi_{\mathrm{s}}}{R_{\mathrm{s}}}+\frac{\chi_{\mathrm{g}}}{R_{\mathrm{g}}+R_{\mathrm{ac}}}+\frac{C_{\mathrm{atm}}}{R_{\mathrm{a}}+R_{\mathrm{b}}}}{\frac{1}{R_{\mathrm{c}}}+\frac{1}{R_{\mathrm{s}}}+\frac{1}{R_{\mathrm{g}}+R_{\mathrm{ac}}}+\frac{1}{R_{\mathrm{a}}+R_{\mathrm{b}}}}$,

where $\chi_{\mathrm{c}}$ is the cuticular compensation point, $\chi_{\mathrm{s}}$ is the stomatal compensation point, $R_{\mathrm{c}}$ is the cuticular resistance, $R_{\mathrm{S}}$ is the stomatal resistance, $R_{\mathrm{g}}$ is the soil diffusion resistance, and $R_{\mathrm{ac}}$ is the in-canopy aerodynamic resistance (Table 1 in detail). While for vegetated surface with saturate soil, $\chi_{\mathrm{cnp}}$ is parameterized as the following:

$\chi_{\text {cnp }}=\frac{\frac{\chi_{\mathrm{c}}}{R_{\mathrm{c}}}+\frac{\chi_{\mathrm{s}}}{R_{\mathrm{s}}}+\frac{\chi_{\mathrm{w}}}{R_{\mathrm{w}}+R_{\mathrm{ac}}}+\frac{C_{\mathrm{atm}}}{R_{\mathrm{a}}+R_{\mathrm{b}}}}{\frac{1}{R_{\mathrm{c}}}+\frac{1}{R_{\mathrm{s}}}+\frac{1}{R_{\mathrm{w}}+R_{\mathrm{ac}}}+\frac{1}{R_{\mathrm{a}}+R_{\mathrm{b}}}}$,

where $\chi_{\mathrm{w}}$ is the air-water compensation point and $R_{\mathrm{W}}$ is the diffusional resistance on water surface.

The governing equation for air-surface exchange in barren or sparsely vegetated land, and over snow/ice surface is

$F_{\mathrm{bls}}=\frac{\Delta t}{R_{\mathrm{a}}+R_{\mathrm{b}}+R_{\mathrm{g}}}\left(\chi_{\mathrm{g}}-C_{\mathrm{atm}}\right)$.

For bare land, $R_{\mathrm{g}}$ is calculated following Zhang and Lindberg (1999):

$R_{\mathrm{g}}=\frac{d}{1.32 \cdot(\sigma-\theta) \cdot D_{0}}$.

For snow/ice surface, $R_{\mathrm{g}}$ is evaluated following Zhang et al. (2012b):

$\frac{1}{R_{\mathrm{g}}}=\frac{\alpha_{\mathrm{Hg}^{0}}}{R_{\mathrm{g}\left(\mathrm{SO}_{2}\right)}}+\frac{\beta_{\mathrm{Hg}^{0}}}{R_{\mathrm{g}\left(\mathrm{O}_{3}\right)}}$, where $R_{\mathrm{g}\left(\mathrm{SO}_{2}\right)}$ and $R_{\mathrm{g}\left(\mathrm{O}_{3}\right)}$ are the diffusion resistances of $\mathrm{SO}_{2}$ and $\mathrm{O}_{3}, \alpha_{\mathrm{Hg}^{0}}$ is the $\mathrm{Hg}^{0}$ scaling factor based on $\mathrm{SO}_{2}$, and $\beta_{\mathrm{Hg}^{0}}$ is the $\mathrm{Hg}^{0}$ scaling factor based on $\mathrm{O}_{3}$. The formulation of $R_{\mathrm{g}\left(\mathrm{SO}_{2}\right)}$ and $R_{\mathrm{g}\left(\mathrm{O}_{3}\right)}$ has been described previously (Zhang et al., 2003; X. Wang et al., 2014). The $\chi_{\mathrm{g}}$ for the air-snow interface is assumed to be $3 \mathrm{ng} \mathrm{m}^{-3}$ based on field measurements at air-snow interface (Mann et al., 2015; Lalonde et al., 2003; Fain et al., 2007; Maxwell et al., 2013). Other parameters in Eqs. (19)-(24) are described in details in X. Wang et al. (2014).

\subsection{Model configuration and data}

The modeling domain is in Lambert conformal projection, with $223 \times 149$ grid cells at a $36 \mathrm{~km}$ spatial resolution. The modeling period is 1 year (2013). Hourly meteorological data are prepared using the Weather Research and Forecasting (WRF) model version 3.7. Sensitivity analysis in $\mathrm{X}$. Wang et al. (2014) showed that accurate representation of environmental parameters (temperature, solar irradiance, etc.) greatly improves the flux estimate. To obtain the best physics and dynamics options of WRF for the China domain, a $L_{25}\left(5^{6}\right)$ orthogonal design of experiments is utilized (Supplement, Table S1). The best combination of meteorological physics options is selected based on model evaluation metrics $R$ (correlation coefficient) and RMSE (root mean square error) between simulated outputs of each combination of options and observed values in 750 meteorological stations. The selected physics options are Thompson (microphysics options), Betts-Miller-Janjic (cumulus parameterization options), RRTMG (radiation physics options), and BouLac (PBL physics options) based on the results of meteorological model performance evaluation (Fig. S1 in the Supplement).

The datasets for surface soil properties ( $1 \mathrm{~km}$ spatial resolution) containing organic matter contents, $\mathrm{pH}$, bulk density, and porosity are adopted from Shangguan et al. (2013). The land cover data ( $1 \mathrm{~km}$ spatial resolution) are obtained from Ran et al. (2012). The land cover map represents the best available datasets and follows the IGBP (International Geosphere-Biosphere Programme) classification system (Fig. S2). The ratio of rice planting fields in China during each month are classified following the method used in Liu et al. (2013). The rice planting seasons are April to October in South China (including double rice planting), and May to October in Northeast China (single rice planting). The LAI data, also with a $1 \mathrm{~km}$ spatial resolution, are adopted from Yuan et al. (2011). The soil Hg content information utilized by Shetty et al. (2008) is updated and greatly expanded with the comprehensive NMPRGS dataset (Li et al., 2014). These high resolution datasets were regridded into the domain specification for each land use using the spatial tools in ArcGIS 10.1. The soil $\mathrm{Hg}$ content in $0-20 \mathrm{~cm}$ surface soil varies with land use types, containing mean concentrations of 119-211, $61-197,80-82,80-82$, and $31-162 \mathrm{ng} \mathrm{g}^{-1}$ of $\mathrm{Hg}$ for for- 


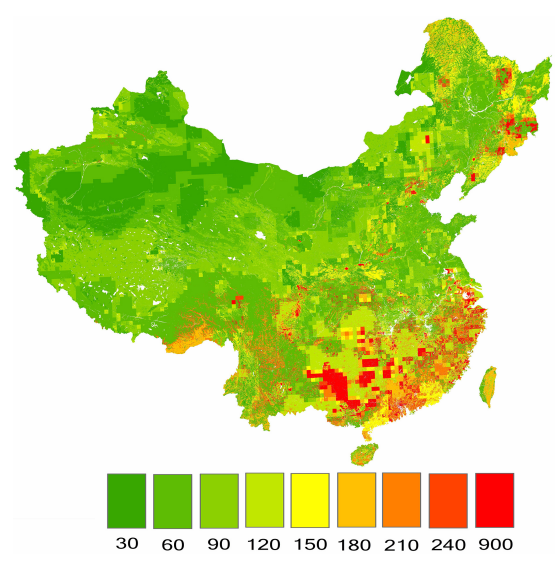

Figure 1. Updated $\mathrm{Hg}$ concentrations $\left(\mathrm{ng} \mathrm{g}^{-1}\right)$ in surface soil (0$20 \mathrm{~cm}$ ) of China. Sampling areas in NMPRGS cover most agriculturally and industrially developed regions of East and Central China, and are presented in more detail in Li et al. (2014).

est ecosystems, shrubland, savanna/grassland, cropland, and other land uses, respectively (Table 1 and Fig. 1). Though the mean $\mathrm{Hg}$ concentration in $0-20 \mathrm{~cm}$ soil profile could somewhat underestimate $\mathrm{Hg}$ concentration in the top soil layer, the dataset is the best available one describing the soil $\mathrm{Hg}$ concentration in China. Datasets of $\mathrm{Hg}$ concentration in the top soil layer (e.g., $0-5 \mathrm{~cm}$ depth) are recommended when they become available.

In the simulation, the validated $\mathrm{Hg}^{0}$ concentration retrieved from the output of the $\mathrm{Hg}$ extension of Community Multi-scale Air Quality modeling system (CMAQ-Hg) version 4.7 for the same modeling period is applied to represent the ambient air concentration of $\mathrm{Hg}^{0}$ (Lin et al., 2010b). The simulation does not incorporate the feedback of the airsurface exchange to the air concentration because the feedback of the air-surface exchange to the air concentration does not significantly modify the atmospheric $\mathrm{Hg}^{0}$ concentration in each grid cell, and the typical variation range of ambient $\mathrm{Hg}^{0}$ concentration is not a sensitivity parameter for flux change (X. Wang et al., 2014). The model algorithms are coded in FORTRAN 90 and Network Common Data Form (NetCDF) version 4.3. The gridded model results are visualized by the Visualization Environmental for Rich Data Interpretation (VERDI) version 1.5.

\section{Results and discussion}

\subsection{Evaluation for soil $\mathrm{Hg}$ reduction scheme}

Values of all model parameters used in the simulation are showed in Table 1. The value of $k_{1}$ is assumed to be $6 \times$ $10^{-9} \mathrm{~m}^{2} \mathrm{~W}^{-1} \mathrm{~s}^{-1}$ based on the relationship between irradiance intensity and apparent photoreduction rate constant in aerated solution observed by Si and Ariya (2011). Considering the $2 \mathrm{~mm}$ maximum photolysis penetration depth in soil
(Hebert and Miller, 1990), the measured rate constant in soil particles (depth $=2.07 \mathrm{~mm}$ ) from Quinones and Carpi (2011) is $2 \times 10^{-3} \mathrm{~m}^{2} \mathrm{~W}^{-1} \mathrm{~h}^{-1}\left(k_{2}\right)$ with respect to the pool of labile $\mathrm{Hg}^{\mathrm{II}}$ available for reduction. The value of $k_{3}$ is assumed to be $1.0 \times 10^{-3} \mathrm{~h}^{-1}$ based on the average rate constants for dark (thermal) reduction (Pannu, 2012). The mean ratio of reducible $\mathrm{Hg}$ in soil is assumed to be 0.03 for the soil with vegetation based on measurements from Pannu (2012). No data are available for the bare soil. Data from Lindberg et al. (1999) imply that Hg-enriched desert soil (1400$5000 \mathrm{ng} \mathrm{g}^{-1}$ total $\mathrm{Hg}$ ) produces a nominal $\mathrm{Hg}^{0}$ efflux in the range from 40 to $60 \mathrm{ng} \mathrm{m}^{-2} \mathrm{~h}^{-1}$. Derived from back calculation taking pore diffusion into account, the fraction of reducible $\mathrm{Hg}$ is predicted at least 10 times lower $(\leq 0.003)$ than that in the soil with vegetation.

Sensitivity analyses using a box model for a typical forest soil are performed to gauge the selected rate coefficients, and the results are shown in Fig. 2. With $k_{1}=6.0 \times$ $10^{-9} \mathrm{~m}^{2} \mathrm{~W}^{-1} \mathrm{~s}^{-1}, k_{2}=2.0 \times 10^{-3} \mathrm{~m}^{2} \mathrm{~W}^{-1} \mathrm{~h}^{-1}, k_{3}=1.0 \times$ $10^{-3} \mathrm{~h}^{-1}$, the $\mathrm{Hg}^{0}$ vapor concentration in soil porous media is estimated to be $4.5 \mathrm{ng} \mathrm{m}^{-3}$, comparable to the measured concentration $\left(4.1 \pm 2.0 \mathrm{ng} \mathrm{m}^{-3}\right)$ in the surface forest floor (Moore and Castro, 2012). This suggests that the selected empirical constants appropriately represent typical environmental conditions. Generally, the range of $\mathrm{Hg}^{0}$ vapor in all simulations is $1.5-6.7 \mathrm{ng} \mathrm{m}^{-3}$. Less than $0.1 \% \mathrm{Hg}^{0}$ vapor is from photoreduction in soil solution as the $\mathrm{Hg}$ pool in soil solution is small ( $\leq 0.1 \%$ of total $\mathrm{Hg}$ concentration). $\mathrm{A} \sim 16 \%$ fraction of the pore $\mathrm{Hg}^{0}$ concentration derives from thermal $\mathrm{Hg}^{\mathrm{II}}$ reduction, contributing to $0.5-1 \mathrm{ng} \mathrm{m}^{-3}$ of $\mathrm{Hg}^{0}$ vapor present in soil gas. $\mathrm{Hg}^{0}$ concentrations in pore gas are typically lower than the $1-2 \mathrm{ng} \mathrm{m}^{-3}$ atmospheric $\mathrm{Hg}$ concentration in background forest at night (Carpi and Lindberg, 1998; Ericksen and Gustin, 2006; Kuiken et al., 2008a, b; Obrist et al., 2014; Fu et al., 2015), suggesting that the forest floor acts as a $\mathrm{Hg}^{0}$ sink during nighttime. This is consistent with the sign of nocturnal fluxes observed over forest floor (Carpi and Lindberg, 1998; Ericksen et al., 2006; Kuiken et al., 2008a, b). Moore and Carpi (2005) reported that the Hg flux under sun-lit condition is 3-5 times higher than the value observed in the dark. The developed model is capable of producing results consistent with the observation that photoreduction on soil particles dominates the formation of $\mathrm{Hg}^{0}$ vapor.

Figure 3 illustrates the model response to the model variables at the two experimental levels in Table 2. The twolevel factorial design of experiments is meant to gauge the extreme variation of flux caused by the possible range of all parameters. This method is statistically robust, and therefore the synergistic and antagonistic interactions among model parameters can be estimated with indications of statistical significance. On average, increasing soil bulk density from 0.1 to $1.5 \mathrm{~g} \mathrm{~cm}^{-3}, \mathrm{Hg}$ content from 10 to $400 \mathrm{ng} \mathrm{g}^{-1}$, soil temperature from 0 to $30^{\circ} \mathrm{C}$, and solar radiation from 0 to $1000 \mathrm{~W} \mathrm{~m}^{-2}$ will significantly enhance the flux by 20 $30 \mathrm{ng} \mathrm{m}^{-2} \mathrm{~h}^{-1}$. Additional $18-20 \mathrm{ng} \mathrm{m}^{-2} \mathrm{~h}^{-1}$ synergistic ef- 
Table 2. Examined model variables and the experimental levels of factorial design for air-soil exchange.

\begin{tabular}{llrr}
\hline Terms & Description & Low level & High level \\
\hline $\mathrm{BD}$ & Soil bulk density $\left(\mathrm{g} \mathrm{cm}^{-3}\right)$ & 0.1 & 1.5 \\
$\mathrm{pH}$ & Soil pH (dimensionless) & 4 & 9 \\
$P$ & Soil total porosity $(\%)$ & 0.05 & 0.5 \\
$T$ & Soil temperature $\left({ }^{\circ} \mathrm{C}\right)$ & 0 & 35 \\
SMOIS & Soil moisture $(\%)$ & 0.05 & 0.5 \\
$R_{0}$ & Solar irradiance above canopy $\left(\mathrm{W} \mathrm{m}^{-2}\right)$ & 0 & 1000 \\
LAI & Leaf area index (dimensionless) & 0 & 7 \\
$\mathrm{GEM}$ & Atmospheric Hg0 concentration $\left(\mathrm{ng} \mathrm{m}^{-3}\right)$ & 1.5 & 5 \\
$\mathrm{Hg}_{\mathrm{s}}$ & Hg concentration in soil $\left(\mathrm{ng} \mathrm{g}^{-1}\right)$ & 10 & 400 \\
$F_{\mathrm{oc}}$ & Soil organic matter content $(\%)$ & 0.5 & 30 \\
$k_{1}$ & Photoreduction rates in soil solution $\left(\mathrm{m}^{2} \mathrm{~W}^{-1} \mathrm{~s}^{-1}\right)$ & $3 \times 10^{-9}$ & $9 \times 10^{-9}$ \\
$k_{2}$ & Photoreduction rates in soil particles $\left(\mathrm{m}^{2} \mathrm{~W}^{-1} \mathrm{~h}^{-1}\right)$ & $0.7 \times 10^{-3}$ & $3.0 \times 10^{-3}$ \\
$k_{3}$ & Nonphotoreduction rates (thermal, $\left.\mathrm{h}^{-1}\right)$ & $1.0 \times 10^{-3}$ & $2.3 \times 10^{-3}$ \\
\hline
\end{tabular}
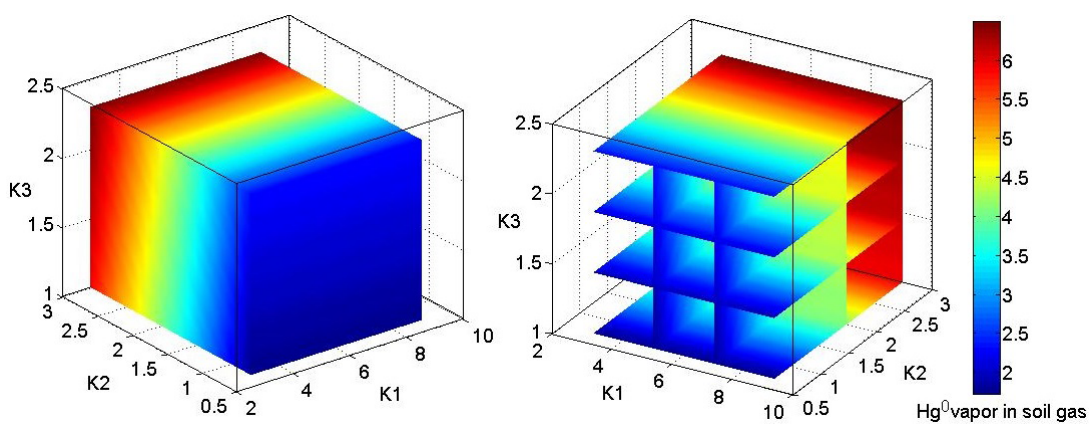

Figure 2. Variation of $\mathrm{Hg}^{0}$ concentrations $\left(\mathrm{ng} \mathrm{m}^{-3}\right)$ in the forest soil pore gas using the typical ranges of kinetic constants for $\mathrm{Hg}^{\mathrm{II}}$ reduction in soil (see text for details): $k_{1}=3.0-9.0 \times 10^{-9} \mathrm{~m}^{2} \mathrm{~W}^{-1} \mathrm{~s}^{-1}, k_{2}=0.7-3.0 \times 10^{-3} \mathrm{~m}^{2} \mathrm{~W}^{-1} \mathrm{~h}^{-1}, k_{3}=1.0-2.3 \times 10^{-3} \mathrm{~h}^{-1}$, soil $\mathrm{Hg}$ content $=150 \mathrm{ng} \mathrm{g}^{-1}, \mathrm{pH}=4$, soil organic content $=20 \%$, soil bulk density $=0.8 \mathrm{~g} \mathrm{~m}^{-3}$, solar irradiance $=1000 \mathrm{~W} \mathrm{~m}{ }^{-2}$, soil temperature $=25^{\circ} \mathrm{C}$, LAI $=5 \mathrm{~m}^{2} \mathrm{~m}^{-2}$, soil moisture content $=20 \%$, and soil porosity $=40 \%$. The environmental conditions are similar to conditions reported by Moore and Castro (2012).

fects from the combination of above parameters are also predicted. Filed measurements suggest the combined effects of soil $\mathrm{Hg}$ content (from 60 to $590 \mathrm{ng} \mathrm{g}^{-1}$ ) and soil temperature (from 5 to $30^{\circ} \mathrm{C}$ ) enhance the flux by $\sim 40 \mathrm{ng} \mathrm{m}^{-2} \mathrm{~h}^{-1}$ (Fu et al., 2012, 2008). On the other hand, increasing leaf area index (LAI) from 0 to $7 \mathrm{~m}^{2} \mathrm{~m}^{-2}$ reduces the flux by $19 \mathrm{ng} \mathrm{m}^{-2} \mathrm{~h}^{-1}$. Furthermore, LAI could offset the positive effects from bulk density, soil $\mathrm{Hg}$ concentration, and solar radiation above canopy, leading to an additional -19 to $-16 \mathrm{ng} \mathrm{m}^{-2} \mathrm{~h}^{-1}$ decrease, indicating that the canopy shading substantially constrains soil $\mathrm{Hg}$ evasion, consistent with the data that the shading could decrease $70-90 \%$ fluxes compared to nonshaded soils in filed measurements (Carpi and Lindberg, 1998; Zhang et al., 2001; Choi and Holsen, 2009). In reality, since the actual variation of the parameters is much smaller than the possible range, the flux change will also be much milder. To illustrate this, we run the model using the center values of selected parameters (i.e., showing the model results by running the model at half of the experimental level). Using the center values of soil $\mathrm{Hg}$ content, LAI, soil bulk density, solar radiation, and soil temperature in Table 2 (close to the environmental parameters in a typical forest ecosystem), the air-soil flux is $4.5 \mathrm{ng} \mathrm{m}^{-2} \mathrm{~h}^{-1}$, similar to the measured fluxes $\left(0.5-9.3 \mathrm{ng} \mathrm{m}^{-2} \mathrm{~h}^{-1}\right)$ in forest ecosystems of China (Fu et al., 2012, 2008).

In the new scheme, the soil organic matter is not incorporated into either $K_{2}$ or $K_{3}$, in accordance with the findings of Pannu (2012). While $\mathrm{Hg}^{0}$ evasion from substrates coated with $\mathrm{HgCl}_{2}$ and humic matter is inversely correlated with humic matter content both in the dark and under irradiation, the inhibitory effect from humic matter is not linear to its content (Mauclair et al., 2008). For instance, relatively small differences are observed at humic matter content $>1 \%$ (Mauclair et al., 2008). In addition, the effect of soil organic matter type has not been comprehensively investigated (Zhang and Lindberg, 1999; Bash et al., 2007). Further studies that quantify the reduction rate constants associated with different types of soil organic matters (or species) under light, as well as field flux data that relate the observed flux intensity to a given type 
Table 3. Mean annual air-surface fluxes and annual total $\mathrm{Hg}$ emissions from individual land use. $\mathrm{SHg}$ is the $\mathrm{Hg}$ content in surface soil $(0-10 \mathrm{~cm}), \mathrm{FF}$ is the $\mathrm{Hg}^{0}$ flux over foliage, and FS is the $\mathrm{Hg}^{0}$ flux over soil.

\begin{tabular}{|c|c|c|c|c|c|c|c|c|}
\hline Type & Description & Area $(\%)$ & $\mathrm{SHg}\left(\mathrm{ng} \mathrm{g}^{-1}\right)$ & $\mathrm{FF}\left(\mathrm{ng} \mathrm{m}^{-2} \mathrm{~h}^{-1}\right)$ & Leaf $(\mathrm{Mg})$ & $\mathrm{FS}\left(\mathrm{ng} \mathrm{m}^{-2} \mathrm{~h}^{-1}\right)$ & Soil (Mg) & Tot $(\mathrm{Mg})$ \\
\hline $\mathrm{C} 1$ & Evergreen needleleaf forest & 5.7 & $186 \pm 74$ & -2.8 & -13.5 & 6.9 & 35.2 & 21.7 \\
\hline $\mathrm{C} 2$ & Evergreen broadleaf forest & 2.6 & $184 \pm 35$ & -2.6 & -6.5 & 6.2 & 16.1 & 9.5 \\
\hline $\mathrm{C} 3$ & Deciduous needleleaf forest & 0.1 & $119 \pm 9$ & -0.2 & -0.03 & 0.7 & 0.1 & 0.1 \\
\hline $\mathrm{C} 4$ & Deciduous broadleaf forest & 3.3 & $143 \pm 47$ & -1.2 & -3.7 & 2.7 & 8.3 & 4.6 \\
\hline $\mathrm{C} 5$ & Mixed forest & 2.4 & $211 \pm 83$ & -2.2 & -4.5 & 4.7 & 10.5 & 6.0 \\
\hline C6 & Closed shrubland & 5.2 & $115 \pm 77$ & -3.2 & -14.1 & 5.6 & 26.0 & 11.9 \\
\hline $\mathrm{C} 7$ & Open shrubland & 0.6 & $155 \pm 72$ & -1.4 & -0.7 & 10.8 & 6.5 & 5.7 \\
\hline $\mathrm{C} 8$ & Woody savanna & 0.3 & $197 \pm 96$ & -4.5 & -1.0 & 12.9 & 3.2 & 2.2 \\
\hline $\mathrm{C} 9$ & Savanna & 0.0 & $157 \pm 47$ & -0.6 & -0.003 & 0.1 & 0.0 & 0.0 \\
\hline $\mathrm{C} 10$ & Grassland & 31.8 & $61 \pm 33$ & -0.8 & -20.3 & 8.0 & 221.8 & 201.4 \\
\hline $\mathrm{C} 11$ & Permanent wetland & 1.1 & $74 \pm 24$ & -0.8 & -0.8 & 9.8 & 10.0 & 9.2 \\
\hline $\mathrm{C} 12$ & Cropland & 20.5 & $80 \pm 59$ & -1.8 & -31.6 & 10.0 & 179.0 & 147.5 \\
\hline $\mathrm{C} 13$ & Cropland mosaic & 1.6 & $82 \pm 74$ & -2.0 & -3.0 & 6.7 & 10.1 & 7.2 \\
\hline $\mathrm{C} 14$ & Urban land & 0.2 & $162 \pm 83$ & -3.6 & -0.7 & 23.3 & 4.4 & 3.7 \\
\hline $\mathrm{C} 15$ & Snow and ice & 0.8 & $31 \pm 15$ & & & 2.0 & 3.1 & 3.1 \\
\hline $\mathrm{C} 16$ & Barren vegetated land & 21.6 & $35 \pm 7$ & & & 1.5 & 22.2 & 22.2 \\
\hline $\mathrm{C} 17$ & Bodies of water & 2.2 & & & & 3.4 & 9.0 & 9.0 \\
\hline Sum & & 100.0 & & & -100.4 & & 565.5 & 465.1 \\
\hline
\end{tabular}

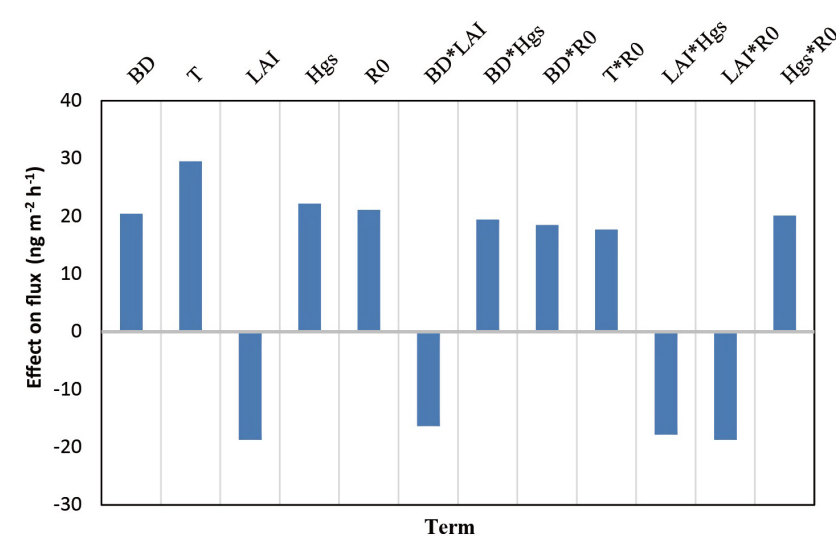

Figure 3. Sensitivity analysis on model parameters for air-soil exchange using a two-level factorial design after prescreening the model variables shown in Table 2 for the identified significant factors. The effects shown in the figure are based on a significance level of $95 \%$ (i.e., $p<0.05$ ).

of organic matter, can improve the present model parameterization.

\subsection{Diurnal variation of natural $\mathrm{Hg}^{0}$ emissions in China}

Table 3 shows the annual mean air-surface fluxes for different land use types. Annual mean air-foliage fluxes range from -0.2 to $-4.5 \mathrm{ng} \mathrm{m}^{-2} \mathrm{~h}^{-1}$, with the highest value over the woody savannas, and the lowest over deciduous forests (Table 3). The diurnal variation for air-foliage flux is displayed in Fig. 4. Higher deposition occurs during midmorning (08:00-10:00 UTC + 8) and late afternoon (16:00-
17:00 UTC + 8) due to the suitable air temperature and solar irradiance that induces $\mathrm{Hg}$ uptake by stomata. The rates of $\mathrm{Hg}$ uptake during midday are comparatively weaker due to the stronger irradiance and higher temperature. This bimodal pattern is consistent with field observations (Lindberg et al., 2002; Poissant et al., 2008; Fritsche et al., 2008; Sommar et al., 2016a), suggesting that the model is capable of simulating the diurnal pattern of air-foliage exchange of $\mathrm{Hg}^{0}$. Such a diurnal pattern is caused by re-emission of the deposited $\mathrm{Hg}$ on the surface foliage through photoreduction under the strong solar radiation during noontime, and the emissions from underlying soil surfaces. Except for urban lands, the strength of diurnal deposition for the other land uses is controlled by LAI, solar radiation, and air temperature. The elevated atmospheric $\mathrm{Hg}$ concentration is an important parameter to induce $\mathrm{Hg}$ uptake by growing foliage in urban lands.

Simulated mean air-soil fluxes range from 0.1 to $23.3 \mathrm{ng} \mathrm{m}^{-2} \mathrm{~h}^{-1}$, with the lowest flux over barren vegetated lands and the highest over urban lands (Table 3). This suggests that the simulated air-soil fluxes greatly vary over different land uses. There are distinct diurnal variations in terrestrial ecosystems (Fig. 5). The diurnal pattern is caused by the variation of solar irradiance, close to zero at night and peaking from 13:00 to 15:00 (UTC + 8). Similar diurnal patterns have been observed during filed measurements for forest, grassland, and cropland in China (Feng et al., 2005; Fu et al., 2008, 2012; Zhu et al., 2013). The degree of diurnal variability for each land use is highly related to the LAI. Higher LAI gives a more intensive canopy shading and largely inhibits $\mathrm{Hg}$ evasion from soil under canopy. This is also the main reason for relative weaker diurnal variation over forest soils compared to shrubland, grassland, and cropland (Fig. 5). The synergistic interactions between low vegetation 

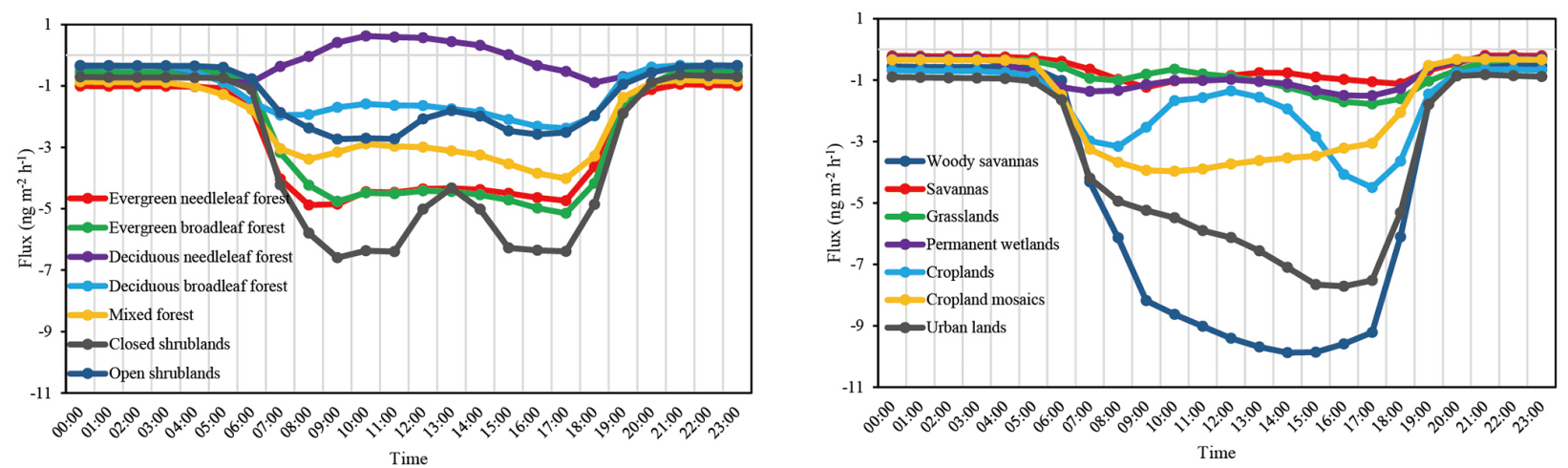

Figure 4. Diurnal variation of mean simulated exchange fluxes of $\mathrm{Hg}^{0}$ over canopy in the model domain $(\mathrm{UTC}+8)$.

cover and high soil concentration (Mean $=162 \pm 83 \mathrm{ng} \mathrm{g}^{-1}$ ) results in the strongest diurnal variation for urban land types.

The simulated annual mean of air-water flux is $3.4 \mathrm{ng} \mathrm{m}^{-2} \mathrm{~h}^{-1}$. The diurnal variability for air-water flux is weaker since wind speed is a more influential driver than irradiance (X. Wang et al., 2014), consistent with the diurnal variation observed in field studies that meteorology and photochemical process are the primary factors (Feng et al., 2002, 2003, 2008; Wang et al., 2006; Fu et al., 2010, 2013a, b).

Overall, the annual net natural emission in China is $465.1 \mathrm{Mg} \mathrm{Hg}$ (Table 3), including $565.5 \mathrm{Mg} \mathrm{yr}^{-1}$ from soil, $9.0 \mathrm{Mg} \mathrm{yr}^{-1}$ from water bodies, and $-100.4 \mathrm{Mg} \mathrm{yr}^{-1}$ from the vegetation. The annual quantity of emission from soil is comparable to the estimate $\left(528 \mathrm{Mg} \mathrm{yr}^{-1}\right)$ based on the scale-up calculation using measured air-soil fluxes (Fu et al., 2015) that suggest emissions from cropland and grassland are the most important contributor. Of the total $\mathrm{Hg}^{0}$ emission estimated by the model, $50 \%$ is from shrubland, savanna, and grassland (C6-C11, $38 \%$ total land use); $33 \%$ is from cropland (C12-C13, $22 \%$ total land use); $9 \%$ is from forest (C1-C5, 14\% total land use); and $8 \%$ is from other land use types. Forest contributes to $28 \%$ of $\mathrm{Hg}$ uptake by foliage; shrubland, savanna, and grassland contribute to $38 \%$; cropland contributes to $33 \%$; and other land use types contribute to $1 \%$.

Although soil $\mathrm{Hg}$ contents in forest ecosystems are 2-4 times higher than that in grassland and cropland, total annual fluxes above the canopy (soil plus foliage) of forest ecosystems are 1-6 times lower than the values in other two types of land uses (Table 3). This highlights the importance of canopy cover in natural emission process of $\mathrm{Hg}^{0}$. It is noteworthy that the land use data are based on the survey in 2000 (Ran et al., 2012). From 2000 to 2013, the forested area in China increased from 14.0 to $21.6 \%$ (FAO, 2014), benefiting from implementation of the governmental Grain for Green Project and stricter natural forest protection actions. Assuming that annual mean air-surface fluxes are at the same level as in this study, the total quantity of natural $\mathrm{Hg}$ emission in 2013 is approximately $5 \%$ smaller than this estimate because of the increasing forest coverage. Given the forest coverage is projected to be $24-26 \%$ during 2030-2050 (FAO, 2014), the quantity of natural $\mathrm{Hg}$ emission in China would decrease by 9-10\% compared to the estimated level of 2013.

\subsection{Spatial distribution of natural $\mathrm{Hg}$ emission in China}

The spatial distribution of annual air-foliage flux can be divided by the well-known geodemographic demarcation line, the Heihe-Tengchong Line (Fig. 6a). The vegetation on the east side of the line is much denser than on the west side of the line because of the higher annual precipitation ( $\geq 800 \mathrm{~mm}$; Fig. S2) that leads to stronger $\mathrm{Hg}^{0}$ uptake by vegetation ( $>90 \%$ of the grid cells have a flux below $-1.0 \mathrm{ng} \mathrm{m}^{-2} \mathrm{~h}^{-1}$ on the east side, compared to $>90 \%$ of the grid cells have a flux above $-0.5 \mathrm{ng} \mathrm{m}^{-2} \mathrm{~h}^{-1}$ on the west side). There is an enhanced $\mathrm{Hg}$ deposition in South China $\left(22-27^{\circ} \mathrm{N}, 105-113^{\circ} \mathrm{E}\right.$; Fig. 6a), with the fluxes ranging -3.8 to $-19.1 \mathrm{ng} \mathrm{m}^{-2} \mathrm{~h}^{-1}$. This can be explained by the elevated atmospheric $\mathrm{Hg}$ concentrations (2-10 $\mathrm{ng} \mathrm{m}^{-3}$ ) and dense vegetation (i.e., high LAI; Fig. S3) that enhance $\mathrm{Hg}$ uptake (Fu et al., 2015; Zhu, 2014). Specifically, evergreen broadleaf forest has the highest LAI compared to other type of forests (Liu et al., 2012) and shows enhanced Hg uptake (up to $-4.5 \mathrm{ng} \mathrm{m}^{-2} \mathrm{~h}^{-1}$ mean flux). Although the direct measurement of $\mathrm{Hg}$ deposition flux through vegetative uptake is still not presently feasible, the measured $\mathrm{Hg}$ input through litterfall (Fu et al., 2015) suggested the rate of $\mathrm{Hg}$ uptake by foliage could be in the range of $4-12 \mathrm{ng} \mathrm{m}^{-2} \mathrm{~h}^{-1}$, comparable to the simulation results in this study.

Figure $6 \mathrm{~b}$ shows the spatial distribution of annual airsoil fluxes. There are three high flux regions (mean flux $\geq 10 \mathrm{ng} \mathrm{m}^{-2} \mathrm{~h}^{-1}$ ): cropland/grassland in South China and Southwest China (mainly in the Guangdong, Guangxi, Guizhou, Yunnan, Chongqing, and Sichuan provinces), cropland in North China (the Heibei, Henan, and Shangdong provinces), and grassland in North China (Inner Mongolia, Shaanxi, and Xinjiang provinces). Such elevated fluxes in the first two regions have been confirmed in field studies 

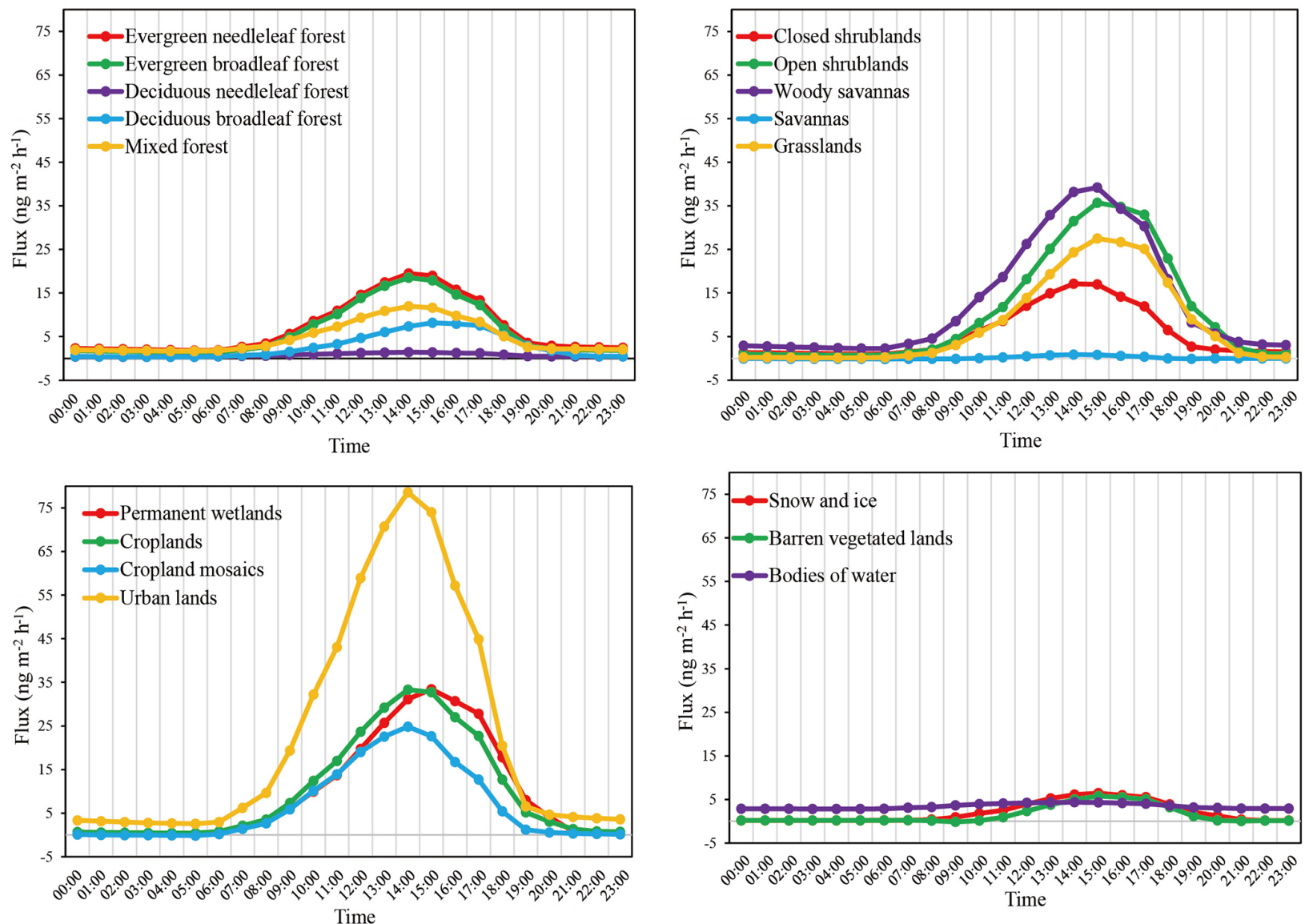

Figure 5. Diurnal variation of mean simulated exchange fluxes of $\mathrm{Hg}^{0}$ over soil and water surfaces in the model domain $(\mathrm{UTC}+8)$.

(Feng et al., 2005; Wang et al., 2005; Wang et al., 2006; Fu et al., 2008; Sommar et al., 2016b). The high fluxes in South China and Southwest China are attributed to the elevated $\mathrm{Hg}$ concentration in soil ( $85 \%$ of grid cells have a soil $\mathrm{Hg}$ content $\geq 100 \mathrm{ng} \mathrm{g}^{-1}$; Fig. 1). Interestingly, soil Hg content is not the primary factor causing the high fluxes in the other two regions ( $70 \%$ of grid cells have a soil $\mathrm{Hg}$ content $\leq 50 \mathrm{ng} \mathrm{g}^{-1}$ ). Dry deposition of PBM and/or GOM plausibly supply the reducible $\mathrm{Hg}$ in soil for gradual reduction and volatilization as $\mathrm{Hg}^{0}$ (Sommar et al., 2016b). The relatively low LAI (Fig. S3), strong solar irradiance, and high soil temperature (Figs. S4-S5) during summer/autumn contribute to the high simulated emissions. The lower simulated fluxes in desert regions compared to fluxes over grassland (Fig. 6b) are caused by the lower fraction of reducible $\mathrm{Hg}$ in soils.

Since the soil $\mathrm{Hg}^{0}$ flux is the primary source of natural $\mathrm{Hg}$ emission, the spatial distribution of the natural $\mathrm{Hg}$ emission is strongly influenced by air-soil flux (Fig. 7a). There is a distinct seasonal variation in the emission quantity: $8 \%$ in winter, $28 \%$ in spring, $51 \%$ in summer, and $13 \%$ in autumn (Fig. 7b-e). Elevated fluxes mainly cluster in South China and Southwest China during winter because of higher soil Hg content (Fig. 1), and relatively higher temperature and stronger irradiance. Highest correlation coefficients are found between the flux and soil $\mathrm{Hg}$ concentration and soil bulk density (Table 4), suggesting that the soil $\mathrm{Hg}^{0}$ pool is a major factor influencing $\mathrm{Hg}$ emission in winter. From the cold to warm season, fluxes gradually increase from low latitude to high latitude with the seasonal change of temperature and solar radiation (Fig. 7b-d). Under the strong irradiance and temperatures in summer, $>65 \%$ of the grid cells in the domain have a flux above $10 \mathrm{ng} \mathrm{m}^{-2} \mathrm{~h}^{-1}$ and the effect of soil $\mathrm{Hg}$ content is relatively weaker (Table 4). In autumn, higher flux occurs over the cropland of Central and North China, and over the regions with high soil Hg content (Fig. 7f) because of the decreasing temperature and solar irradiance in the south and the influence of soil $\mathrm{Hg}$ content in the north. Overall, $72 \%$ of natural $\mathrm{Hg}$ emission occurs from May to September, with higher emission over grassland and cropland in North China in these months.

It is worth noting that parts of regions in South China $\left(23-31^{\circ} \mathrm{N}, 110-120^{\circ} \mathrm{E}\right.$; mainly in the Fujian, Jiangxi, Hunan, Hubei, and Anhui provinces) and Northeast China (39$51^{\circ} \mathrm{N}, 130-134^{\circ} \mathrm{E}$; mainly in the Liaoning, Jilin, and Heilongjiang provinces) have relatively lower fluxes $(-6.9-$ $9.0 \mathrm{ng} \mathrm{m}^{-2} \mathrm{~h}^{-1}$ ) during summer and autumn (Fig. 7e-d). In 

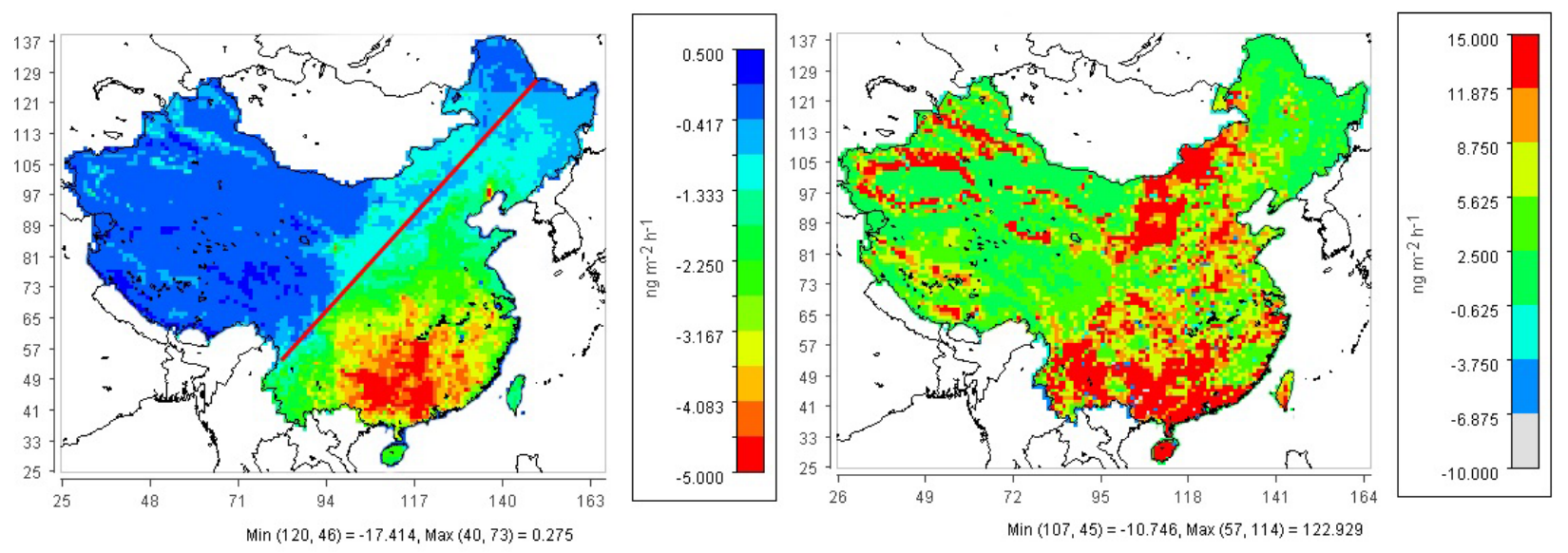

Figure 6. Simulated results of (a) mean annual air-foliage flux and (b) mean annual air-soil flux in the study domain.

Table 4. Pearson correlations between mean total fluxes and major controlling environmental parameters in each season.

\begin{tabular}{lrrrr}
\hline Term & Winter & Spring & Summer & Autumn \\
\hline LAI & $-0.14^{\mathrm{b}}$ & $-0.24^{\mathrm{a}}$ & $-0.39^{\mathrm{a}}$ & $-0.30^{\mathrm{a}}$ \\
Soil temperature & $0.27^{\mathrm{a}}$ & $0.35^{\mathrm{a}}$ & $0.54^{\mathrm{a}}$ & $0.38^{\mathrm{a}}$ \\
Solar radiation & $0.27^{\mathrm{a}}$ & $0.32^{\mathrm{a}}$ & $0.59^{\mathrm{a}}$ & $0.36^{\mathrm{a}}$ \\
Soil Hg concentration & $0.47^{\mathrm{a}}$ & $0.13^{\mathrm{b}}$ & 0.02 & $0.39^{\mathrm{a}}$ \\
Soil bulk density & $0.41^{\mathrm{a}}$ & $0.16^{\mathrm{b}}$ & 0.04 & $0.32^{\mathrm{a}}$ \\
\hline a means $p<0.01$ and $^{\mathrm{b}}$ means $p<0.05$. & & &
\end{tabular}

addition to the impact from the intensive canopy cover in forested areas (Fig. S2), agricultural activities in these regions also contribute to the smaller fluxes. Based on Liu et al. (2013), $60 \%$ croplands in these regions are flooded for rice planting in summer and autumn. Field-scale flux measurement using micrometeorological methods (i.e., aerodynamic gradient method) suggest that a typical oilseedrice rotated cropland in Southwest China is a significant source during oilseed planting seasons with fluxes of 10.1$89.4 \mathrm{ng} \mathrm{m}^{-2} \mathrm{~h}^{-1}$ and a mild sink during rice planting seasons with fluxes of -3.4 to $-15.8 \mathrm{ng} \mathrm{m}^{-2} \mathrm{~h}^{-1}$ (Zhu, 2014). The model also successfully simulates such a pattern, with simulated fluxes at $1.1-101.5 \mathrm{ng} \mathrm{m}^{-2} \mathrm{~h}^{-1}$ (Fig. 7b-c) during winter and earlier spring when croplands are not flooded and at -3.5 to $1.5 \mathrm{ng} \mathrm{m}^{-2} \mathrm{~h}^{-1}$ during the rice growing season (Fig. S6). Overall, $3.3 \mathrm{Mg} \mathrm{Hg}^{0}$ is predicted to deposit into rice paddies during the rice growing season, with $56 \%$ of the deposition occurring in summer, $41 \%$ in autumn, and $3 \%$ in late spring.

\subsection{Verification of model estimates}

For the first time, the simulated natural $\mathrm{Hg}$ emission in China is verified against field observational data in this study. The dataset of $\mathrm{Hg}$ deposition through litterfall is utilized for verifying the simulated air-foliage fluxes because of two rea- sons: (1) it has been shown that $\mathrm{Hg}$ deposition through litterfall dominates dry deposition $(\geq 70 \%)$ in the forests of China (Fu et al., 2015), and the annual $\mathrm{Hg}$ deposition through litterfall has been used as a surrogate to constrain air-foliage fluxes in forest ecosystems (Risch et al., 2012; Zhang et al., 2012a); and (2) the litterfall data in China comprehensively include different forest types compared to the limited locations where air-foliage flux data are available. For verifying the exchange fluxes over water and soil surfaces, the flux measurements over forest soil, grassland, cropland, and water bodies in China (Table S2) are utilized.

To estimate the annual $\mathrm{Hg}$ deposition through litterfall in the study domain, a Monte Carlo simulation (described in details in the Supplement) is applied for constructing the probability distribution of the $\mathrm{Hg}$ deposition through litterfall using litter biomass production and litterfall $\mathrm{Hg}$ concentration in China reported in peer-reviewed literature (Fig. 8). The sampling locations include 20 sites in Tibetan Plateau, 27 sites for evergreen forests, and 12 sites for deciduous forests. The quality-assured data of litter biomass production (number of replicates $\geq 3$, collector size $=1 \mathrm{~m}^{2}$ ) are obtained from the China National Knowledge Infrastructure (CNKI). This dataset includes the measurements at 5 sites in Tibetan Plateau, 277 sites for evergreen forests, 74 sites for deciduous forests, and 61 sites for mixed forests.

Figure $\mathrm{S} 7$ shows the observed $\mathrm{Hg}$ concentrations in litter. The $\mathrm{Hg}$ concentration for evergreen forest ranges from 17 to $120 \mathrm{ng} \mathrm{g}^{-1}$ with a mean of $52 \pm 26 \mathrm{ng} \mathrm{g}^{-1}$. For deciduous forest, the range is $21-62 \mathrm{ng} \mathrm{g}^{-1}$ with a mean of $38 \pm 12 \mathrm{ng} \mathrm{g}^{-1}$. The difference between the concentrations observed in evergreen forests and in deciduous forests is significant (paired $t$ test, $p<0.05$ ). The $\mathrm{Hg}$ concentration in litter for deciduous forest in China is comparable to the values reported for the same forest type in Europe and North America $(p=0.101)$. Hg deposition through litterfall in evergreen broadleaf forest $(\mathrm{C} 2$, refer to Table 3 for the land use type) ranges from 26 to $72 \mu \mathrm{g} \mathrm{m}^{-2} \mathrm{yr}^{-1}$ 

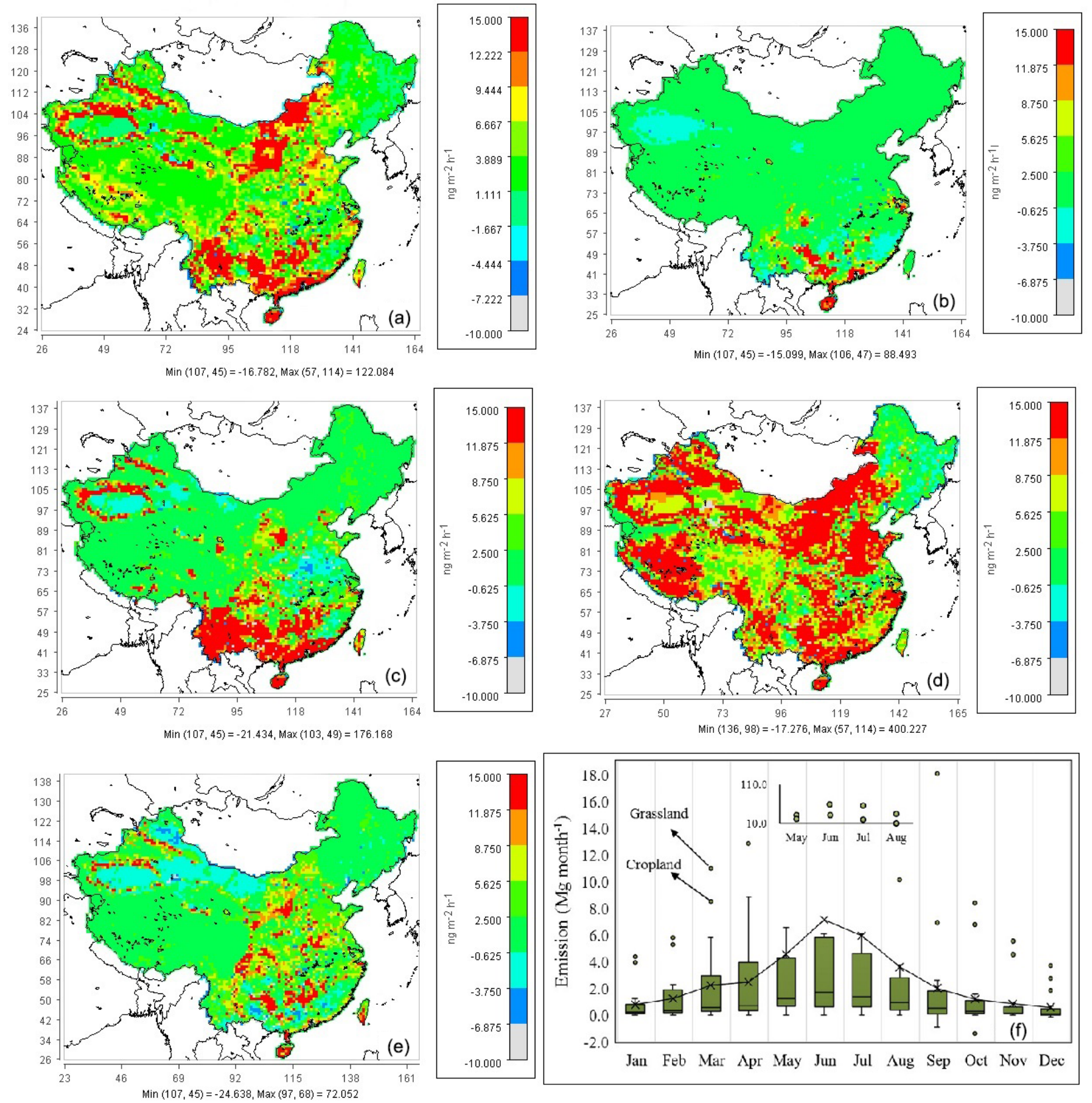

Figure 7. Model estimates of (a) annual mean $\mathrm{Hg}^{0}$ fluxes in the model domain, (b) seasonal mean $\mathrm{Hg}^{0}$ fluxes in winter, (c) seasonal mean

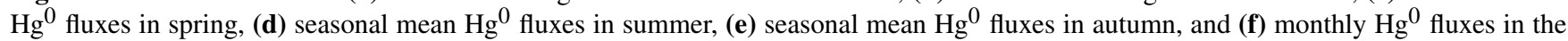
grid cells (box and whisker chart showing maximum, 75th percentile, mean, median, 25th percentile, and minimum).

( $n=5$ sites) with a mean of $43 \pm 27 \mu \mathrm{g} \mathrm{m}^{-2} \mathrm{yr}^{-1}$ (Fu et al., 2015; Ma et al., 2015; Wang et al., 2009), consistent with the $\mathrm{Hg}$ deposition estimated by a Monte Carlo simulation (mean $=37 \pm 19 \mu \mathrm{g} \mathrm{m}^{-2} \mathrm{yr}^{-1} ; 95 \%$ confidence interval is $4-89 \mu \mathrm{g} \mathrm{m}^{-2} \mathrm{yr}^{-1}$ ). The model-estimated $\mathrm{Hg}$ deposition for $\mathrm{C} 1, \mathrm{C} 3, \mathrm{C} 4$, and $\mathrm{C} 5$ is $22 \pm 10,15 \pm 7,16 \pm 11$, and $17 \pm 8 \mu \mathrm{g} \mathrm{m}^{-2} \mathrm{yr}^{-1}$, respectively.

The measured air-soil flux (Table S2) ranges from -1.4 to $20.7 \mathrm{ng} \mathrm{m}^{-2} \mathrm{~h}^{-1}$ over forest soil $(n=19$; mean $=6.1 \pm$
$5.1 \mathrm{ng} \mathrm{m}^{-2} \mathrm{~h}^{-1}$ ), from -18.7 to $114 \mathrm{ng} \mathrm{m}^{-2} \mathrm{~h}^{-1}$ over grassland $\left(n=14\right.$; mean $\left.=26 \pm 36 \mathrm{ng} \mathrm{m}^{-2} \mathrm{~h}^{-1}\right)$, from -4.1 to $135 \mathrm{ng} \mathrm{m}^{-2} \mathrm{~h}^{-1}$ over cropland $(n=33 ;$ mean $=21.3 \pm$ $\left.36.7 \mathrm{ng} \mathrm{m}^{-2} \mathrm{~h}^{-1}\right)$. For water body $(n=51)$, the flux range is $0-43.8 \mathrm{ng} \mathrm{m}^{-2} \mathrm{~h}^{-1}$ with a mean of $4.6 \pm 6.6 \mathrm{ng} \mathrm{m}^{-2} \mathrm{~h}^{-1}$ (Table S2). The mean fluxes from May to October are substantially higher than those from November to April: 3.3 times for water surface $(p=0.004), 3.2$ times higher for forest soil $(p=0.08)$, and 1.4 times for cropland $(p=0.50)$. A reverse 

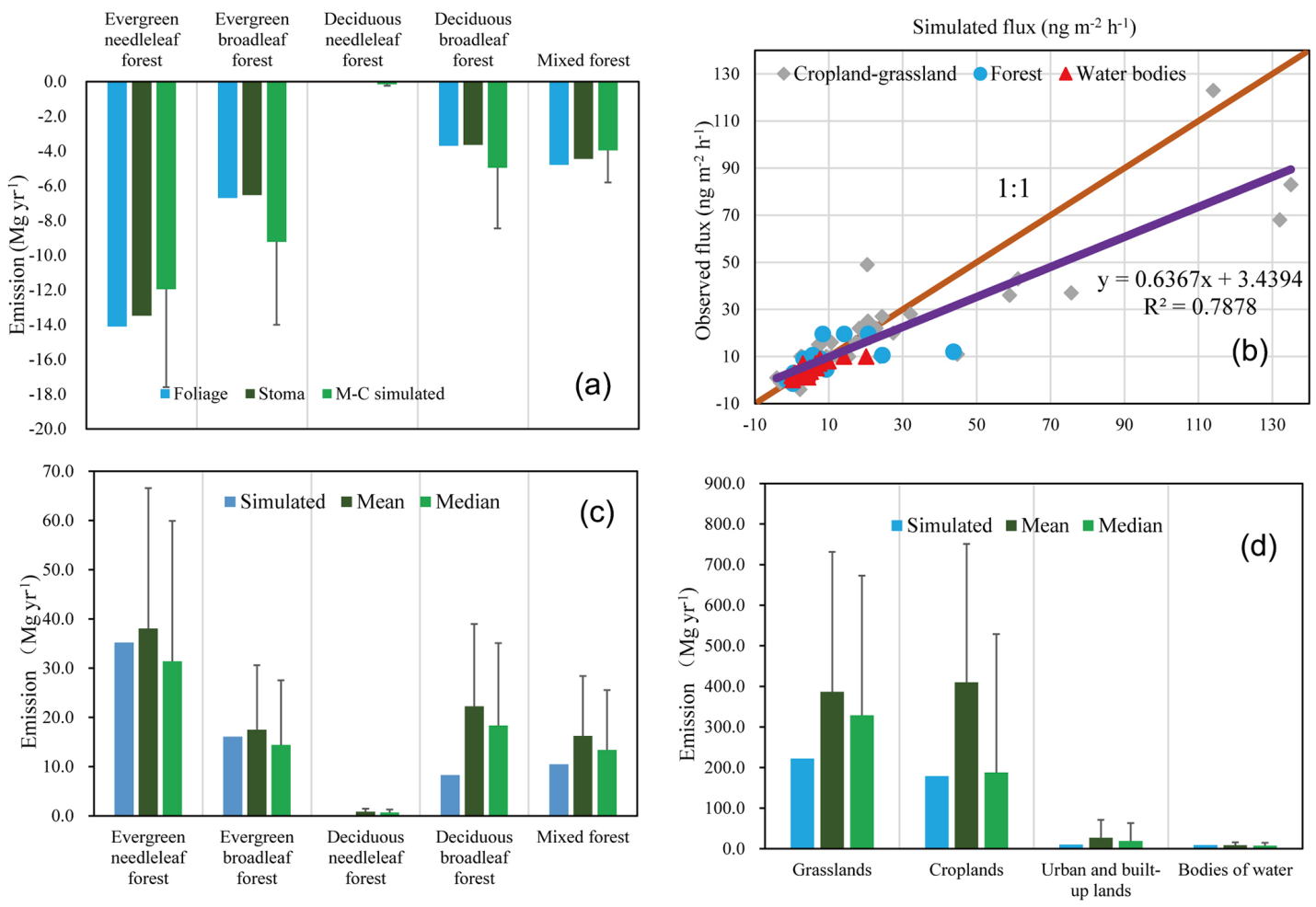

Figure 8. Model verification: (a) model estimates of $\mathrm{Hg}^{0}$ uptake by foliage (which include the uptake by stoma and the re-emission from cuticle) and by stoma, compared to the estimate (mean and $95 \%$ confidence interval) of $\mathrm{Hg}^{0}$ uptake using a Monte Carlo (M-C) simulation of the observational data; (b) scatter plot of the observed fluxes vs. simulated fluxes for different land uses (the flux observations are described in detailed in Table S2), (c) comparison between simulated exchange and measured exchange over soil under canopy, and (d) comparison between simulated exchange and measured exchange over grasslands, cropland, and water surface. The mean and median of Fig. $8 \mathrm{c}$ and $\mathrm{b}$ are based on the filed data from peer-reviewed literature ( $n=19$ for forests; $n=12$ for grasslands; $n=42$ for croplands; $n=51$ for water bodies). Note that the exchange over deciduous needleleaf forests in (a) is small because of the small forest area.

trend is found for grassland, which has higher mean flux in cold seasons (50\% higher, $p=0.36)$. More measurements in grassland where few data exist will greatly improve the accuracy of the current estimate.

Figures S8, S9, and 8a compare the model estimates to the mean and variability level predicted by a Monte Carlo simulation using field data. The annual $\mathrm{Hg}$ uptake simulated by the bidirectional exchange model is not significantly different from the field observations $(p>0.05, t$ test $)$ and the spatial patters are similar (Fig. S8) in coniferous forest ecosystems, demonstrating the model capability for simulating the air-foliage flux. However, the bidirectional exchange model did not capture the spatial distribution of air-foliage flux in broadleaf forest ecosystems (particularly in evergreen broadleaf forest; Fig. S9). One possible explanation is that the resistance terms obtained from temperate/boreal forests (Zhang et al., 2012b) may not appropriately represent the value in evergreen broadleaf forests. Filed measurements suggests that the leaf stomatal conductance of broadleaf is usually higher than the value of needleleaf (Wang et al., 2015; Ishida et al., 2006; Sobrado, 1991; Eamus et al., 1999), leading to a larger air-foliage $\mathrm{Hg}^{0}$ exchange (Graydon et al., 2006). Further studies on the $\mathrm{Hg}$ transport and chemical reactions at the air-foliage interface in evergreen broadleaf forests will help constrain the model.

Figure $8 \mathrm{~b}$ shows the scatter plot of the measured and model-predicted fluxed over soil and water $\left(R^{2}=0.73\right)$. Modeling results for over water surfaces and soil under forest canopy also agree with filed data (Fig. 8c-d). The model results somewhat underestimate the high fluxes ( $\geq 30 \mathrm{ng} \mathrm{m}^{-2} \mathrm{~h}^{-1}$; Fig. S9.2) measured over grassland and cropland (Fig. 8d), which can be attributed to several possible reasons. One reason is the bias caused by the comparatively coarser spatial resolution $(36 \mathrm{~km})$ of meteorological parameters and soil properties that limit the reproduction of the instantaneously measured fluxes at observational sites. In addition, the limited mechanistic understanding of the reemission process after $\mathrm{Hg}$ dry deposition (Gustin et al., 2015, 2008b; Lindberg et al., 2007; Ariya et al., 2015) complicates model parameterization. Finally, the uncertainties caused by flux quantification methodology (Lin et al., 2012; Zhu et al., $2015 \mathrm{a}, \mathrm{b}$ ) and the typically short campaign periods (mostly ranging from several days to a couple of weeks) could bias the measurement data (Feng et al., 2005; Fu et al., 2008, 
2012, 2015; Zhu et al., 2015a, b). Improvement of flux methods and extended campaign periods at more study sites for cropland/grassland will help constrain the model estimates.

\subsection{Comparison with earlier estimates and implications on $\mathrm{Hg}$ emission outflow in China}

Figures $\mathrm{S} 10$ and $\mathrm{S} 11$ show the gridded natural $\mathrm{Hg}$ emission in the east Asian domain reported by Shetty et al. (2008) and S. Wang et al. (2014), which have two distinct differences compared to the model estimate in this study. One is the role of vegetation in natural $\mathrm{Hg}$ emission, the other is spatial distribution of the emission. Vegetation is clearly an important sink of $\mathrm{Hg}^{0}$ with the mechanistic model algorithms implemented in this study and the shading of vegetation suppresses $\mathrm{Hg}$ evasion from soil under canopy. In contrast, vegetation is considered a major source, accounting for $76 \%$ of total emissions in Shetty et al. (2008) because the model treats $\mathrm{Hg}$ evasion as an evapotranspiration process that transports $\mathrm{Hg}$ from root zone through vascular tissues in foliage (Gbor et al., 2007; Shetty et al., 2008). Recent experimental evidence using stable $\mathrm{Hg}$ isotope tracers points to exclusion of this pathway for cereal plants (Cui et al., 2014). In addition, $\mathrm{Hg}$ isotopic signatures observed in air and leaf samples (Demers et al., 2013; Yin et al., 2013) and during air-foliage exchange process (Graydon et al., 2006; Gustin et al., 2008a) indicate uptake of atmospheric $\mathrm{Hg}$ by foliage, pointing to vegetation as an $\mathrm{Hg}^{0}$ sink. In contrast to the spatial distribution of the emission in this study, the earlier $\mathrm{Hg}^{0}$ emission estimates occur mainly in the regions on the east side of the Heihe-Tengchong Line (Shetty et al., 2008; S. Wang et al., 2014), due to the spatial distribution of vegetation (Shetty et al., 2008), or soil Hg content (S. Wang et al., 2014).

This study advances upon the earlier estimates (Shetty et al., 2008; S. Wang et al., 2014) in three areas. Firstly, the recent soil survey data, including soil $\mathrm{Hg}$ content and other soil characteristics, are a major advantage in this study. The soil Hg data applied in Shetty et al. (2008) are outdated with a coarse spatial resolution, while the data in S. Wang et al. (2014) are based on the output of the global terrestrial $\mathrm{Hg}$ model in GEOS-Chem, calculated from $\mathrm{Hg} / \mathrm{C}$ ratios. Secondly, the mechanistic model scheme better describes the air-surface exchange process compared to the regression and evapotranspiration in the earlier studies. Finally, the model estimates are verified against the field flux data with generally good agreement, which has not been attempted in earlier works.

Although the total quantity of annual natural emission estimated in this study is comparable to earlier estimates (400-600 $\mathrm{Mg} \mathrm{yr}^{-1}$ ) by Shetty et al. (2008) and S. Wang et al. (2014), the distinct spatial distribution of natural emissions simulated in this study may alter the current understanding of $\mathrm{Hg}$ emission outflow from China assessed by Lin et al. (2010b). The outflow of $\mathrm{Hg}$ emissions in China is mainly driven by the prevailing west-wind drift (Lin et al., 2010b; Chen et al., 2014). The predominant natural Hg emission in the west side of model domain results in a longer residence time of evaded $\mathrm{Hg}$, which can be more readily oxidized and deposited within the domain. Furthermore, the dense vegetation in the east side of the domain can also help capture the nature $\mathrm{Hg}^{0}$ emission, potentially leading to substantially larger domestic deposition and smaller quantity of outflow compared to the estimates by Lin et al. (2010b). We are presently reassessing the emission outflow using a regional chemical transport model (e.g., CMAQ-Hg) and a similar mass balance approach by Lin et al. (2010b) and will report the model results in a future paper.

\section{Conclusions}

Using a mechanistic model incorporating the present state of understanding in $\mathrm{Hg}$ transformation in soils and on foliage surface with up-to-date datasets of soil characteristics and land use changes, the natural emission of $\mathrm{Hg}^{0}$ vapor in China is estimated to be $465.1 \mathrm{Mg} \mathrm{yr}^{-1}$, including $565.5 \mathrm{Mg} \mathrm{yr}^{-1}$ of emission from soils, $9.0 \mathrm{Mg} \mathrm{yr}^{-1}$ of emission from water bodies, and $-100.4 \mathrm{Mg} \mathrm{yr}^{-1}$ deposition (uptake) by vegetation. The air-surface exchange is strongly dependent on land use and meteorology, with $9 \%$ of net emission from forest ecosystems; $50 \%$ from shrubland, savanna, and grassland; $33 \%$ from cropland; and $8 \%$ from other land uses. Given the large agricultural land area in China, farming activities play an important role on the air-surface exchange. Particularly, rice fields shift from a net sink (3.3 Mg uptake) during the growing season in rice paddy to a net source during the season when the farmland is not flooded. The estimated natural $\mathrm{Hg}^{0}$ emission in this study yields similar $\mathrm{Hg}^{0}$ evasion quantity but exhibits contrasting spatial distribution compared to the estimate by Shetty et al. (2008). The difference in the spatial patterns may alter the current understanding of $\mathrm{Hg}$ emission outflow from China as reported by Lin et al. (2010b) because of a substantial amount of natural $\mathrm{Hg}^{0}$ emission occurs in West China, which requires further assessment.

For future model improvement, studies focusing on fundamental understanding of $\mathrm{Hg}^{\mathrm{II}}$ reduction in soil (especially the role of soil organic matter, contribution of photochemical and nonchemical pathways, and radiation transfer in soil) and air-vegetation exchange mechanisms are needed. Continuous updates on the data of soil characteristics and $\mathrm{Hg}$ content are also essential. More field data for model performance evaluation are also important for constraining the model. In particular, data of air-foliage flux, and air-soil flux over cropland and grassland in the remote regions of North China are valuable for model calibration.

\section{Data availability}

The code related to this article is available online at doi:10.13140/RG.2.2.36661.68325 (https: 
//www.researchgate.net/publication/307855069_The bidirectional_air-surface_exchange_model_for_elemental_ mercury_vapor).

\section{The Supplement related to this article is available online at doi:10.5194/acp-16-11125-2016-supplement.}

Acknowledgements. This work was funded by National "973" Program of China (2013CB430003) and State Key Laboratory of Environmental Geochemistry, IGCAS. The funding support is gratefully acknowledged.

Edited by: L. Zhang

Reviewed by: three anonymous referees

\section{References}

Ariya, P. A., Amyot, M., Dastoor, A., Deeds, D., Feinberg, A., Kos, G., Poulain, A., Ryjkov, A., Semeniuk, K., Subir, M., and Toyota, K.: Mercury Physicochemical and Biogeochemical Transformation in the Atmosphere and at Atmospheric Interfaces: A Review and Future Directions, Chem. Rev., 115, 3760-3802, 2015.

Bash, J. O.: Description and initial simulation of a dynamic bidirectional air-surface exchange model for mercury in Community Multiscale Air Quality (CMAQ) model, J. Geophys. Res.Atmos., 115, 621-631, doi:10.1029/2009JD012834, 2010.

Bash, J. O., Miller, D. R., Meyer, T. H., and Bresnahan, P. A.: Northeast United States and Southeast Canada natural mercury emissions estimated with a surface emission model, Atmos. Environ., 38, 5683-5692, 2004.

Bash, J. O., Bresnahan, P., and Miller, D. R.: Dynamic surface interface exchanges of mercury: A review and compartmentalized modeling framework, J. Appl. Meteorol. Climatol., 46, 16061618, doi:10.1175/jam2553.1, 2007.

Carpi, A. and Lindberg, S. E.: Application of a Teflon (TM) dynamic flux chamber for quantifying soil mercury flux: Tests and results over background soil, Atmos. Environ., 32, 873-882, 1998.

Chen, L., Wang, H. H., Liu, J. F., Tong, Y. D., Ou, L. B., Zhang, W., Hu, D., Chen, C., and Wang, X. J.: Intercontinental transport and deposition patterns of atmospheric mercury from anthropogenic emissions, Atmos. Chem. Phys., 14, 10163-10176, doi:10.5194/acp-14-10163-2014, 2014.

Choi, H. D. and Holsen, T. M.: Gaseous mercury fluxes from the forest floor of the Adirondacks, Environ. Pollut., 157, 592-600, 2009.

Ciani, A., Goss, K. U., and Schwarzenbach, R. P.: Light penetration in soil and particulate minerals, Eur. J. Soil. Sci., 56, 561-574, 2005.

Cui, L., Feng, X., Lin, C.-J., Wang, X., Meng, B., Wang, X., and Wang, H.: Accumulation and translocation of ${ }^{198} \mathrm{Hg}$ in four crop species, Environ. Toxicol. Chem., 33, 334-340, 2014.

Demers, J. D., Blum, J. D., and Zak, D. R.: Mercury isotopes in a forested ecosystem: Implications for air-surface exchange dy- namics and the global mercury cycle, Global Biogeochem. Cy., 27, 222-238, doi:10.1002/gbc.20021, 2013.

Eamus, D., Myers, B., Duff, G., and Williams, R.: A cost-benefit analysis of leaves of eight Australian savanna tree species of differing leaf life-span, Photosynthetica, 36, 575-586, 1999.

Ericksen, J. and Gustin, M. S.: Air-surface exchange of mercury with soils amended with ash materials, J. Air Waste Manage., 56, 977-992, 2006.

Ericksen, J. A., Gustin, M. S., Xin, M., Weisberg, P. J., and Fernandez, G. C. J.: Air-soil exchange of mercury from background soils in the United States, Sci Total Environ., 366, 851-863, 2006.

Fain, X., Grangeon, S., Bahlmann, E., Fritsche, J., Obrist, D., Dommergue, A., Ferrari, C. P., Cairns, W., Ebinghaus, R., Barbante, C., Cescon, P., and Boutron, C.: Diurnal production of gaseous mercury in the alpine snowpack before snowmelt, J. Geophys. Res.-Atmos., 112, 5671-5674, doi:10.1029/2007JD008520, 2007.

FAO: State of the World's Forests 2014, FOOD AND AGRICULTURE ORGANIZATION OF THE UNITED NATIONS, Rome, 93-100, 2014.

Feng, X., Qiu, G., Wang, S., and Shang, L.: Distribution and speciation of mercury in surface waters in mercury mining areas in Wanshan, Southwestern China, J. Phys. Iv, 107, 455-458, 2003.

Feng, X. B., Sommar, J., Gardfeldt, K., and Lindqvist, O.: Exchange flux of total gaseous mercury between air and natural water surfaces in summer season, Sci. China Ser. D, 45, 211-220, 2002.

Feng, X. B., Wang, S. F., Qiu, G. A., Hou, Y. M., and Tang, S. L.: Total gaseous mercury emissions from soil in Guiyang, Guizhou, China, J. Geophys. Res.-Atmos., 110, 1891-1904, doi:10.1029/2004JD005643, 2005.

Feng, X. B., Wang, S. F., Qiu, G. G., He, T. R., Li, G. H., Li, Z. G., and Shang, L. H.: Total gaseous mercury exchange between water and air during cloudy weather conditions over Hongfeng Reservoir, Guizhou, China, J. Geophys. Res.-Atmos., 113, 797801, doi:10.1029/2007JD009600, 2008.

Fritsche, J., Wohlfahrt, G., Ammann, C., Zeeman, M., Hammerle, A., Obrist, D., and Alewell, C.: Summertime elemental mercury exchange of temperate grasslands on an ecosystem-scale, Atmos. Chem. Phys., 8, 7709-7722, doi:10.5194/acp-8-7709-2008, 2008.

Fu, X. W., Feng, X. B., and Wang, S. F.: Exchange fluxes of $\mathrm{Hg}$ between surfaces and atmosphere in the eastern flank of Mount Gongga, Sichuan province, southwestern China, J. Geophys Res.-Atmos., 113, 253-270, doi:10.1029/2008JD009814, 2008.

Fu, X. W., Feng, X. B., Zhang, G., Xu, W. H., Li, X. D., Yao, H., Liang, P., Li, J., Sommar, J., Yin, R. S., and Liu, N.: Mercury in the marine boundary layer and seawater of the South China Sea: Concentrations, sea/air flux, and implication for land outflow, J. Geophys. Res.-Atmos., 115, 620-631, doi:10.1029/2009JD012958, 2010.

Fu, X. W., Feng, X. B., Zhang, H., Yu, B., and Chen, L. G.: Mercury emissions from natural surfaces highly impacted by human activities in Guangzhou province, South China, Atmos. Environ., 54, 185-193, 2012.

Fu, X. W., Feng, X. B., Guo, Y. N., Meng, B., Yin, R. S., and Yao, H.: Distribution and production of reactive mercury and dissolved gaseous mercury in surface waters and water/air mercury 
flux in reservoirs on Wujiang River, Southwest China, J. Geophys. Res.-Atmos., 118, 3905-3917, 2013a.

Fu, X. W., Feng, X. B., Yin, R. S., and Zhang, H.: Diurnal variations of total mercury, reactive mercury, and dissolved gaseous mercury concentrations and water/air mercury flux in warm and cold seasons from freshwaters of southwestern China, Environ. Toxicol. Chem., 32, 2256-2265, 2013 b.

Fu, X. W., Zhang, H., Yu, B., Wang, X., Lin, C.-J., and Feng, X. B.: Observations of atmospheric mercury in China: a critical review, Atmos. Chem. Phys., 15, 9455-9476, doi:10.5194/acp-15-94552015, 2015.

Gbor, P. K., Wen, D. Y., Meng, F., Yang, F. Q., Zhang, B. N., and Sloan, J. J.: Improved model for mercury emission, transport and deposition, Atmos. Environ., 40, 973-983, doi:10.1016/j.atmosenv.2005.10.040, 2006.

Gbor, P. K., Wen, D. Y., Meng, F., Yang, F. Q., and Sloan, J. J.: Modeling of mercury emission, transport and deposition in North America, Atmos. Environ., 41, 1135-1149, doi:10.1016/j.atmosenv.2006.10.005, 2007.

Graydon, J. A., St Louis, V. L., Lindberg, S. E., Hintelmann, H., and Krabbenhoft, D. P.: Investigation of mercury exchange between forest canopy vegetation and the atmosphere using a new dynamic chamber, Environ. Sci. Technol., 40, 4680-4688, 2006.

Gustin, M. S., Lindberg, S. E., and Weisberg, P. J.: An update on the natural sources and sinks of atmospheric mercury, Appl. Geochem., 23, 482-493, 2008a.

Gustin, M. S., Lindberg, S. E., and Weisberg, P. J.: An update on the natural sources and sinks of atmospheric mercury, Appl. Geochem., 23, 482-493, doi:10.1016/j.apgeochem.2007.12.010, 2008b.

Gustin, M. S., Amos, H. M., Huang, J., Miller, M. B., and Heidecorn, K.: Measuring and modeling mercury in the atmosphere: a critical review, Atmos. Chem. Phys., 15, 5697-5713, doi:10.5194/acp-15-5697-2015, 2015.

He, F., Zheng, W., Liang, L. Y., and Gu, B. H.: Mercury photolytic transformation affected by low-molecular-weight natural organics in water, Sci. Total Environ., 416, 429-435, 2012.

Hebert, V. R. and Miller, G. C.: Depth dependence of direct and indirect photolysis on soil surfaces, J. Agr. Food Chem., 38, 913918, doi:10.1021/jf00093a069, 1990.

Hood, A., Gutjahr, C. C. M., and Heacock, R. L.: Organic Metamorphism and the Generation of Petroleum, AAPG Bulletin, 59, 986-996, 1975.

Horowitz, H. M., Jacob, D. J., Amos, H. M., Streets, D. G., and Sunderland, E. M.: Historical Mercury Releases from Commercial Products: Global Environmental Implications, Environ. Sci. Technol., 48, 10242-10250, 2014.

Ishida, A., Diloksumpun, S., Ladpala, P., Staporn, D., Panuthai, S., Gamo, M., Yazaki, K., Ishizuka, M., and Puangchit, L.: Contrasting seasonal leaf habits of canopy trees between tropical drydeciduous and evergreen forests in Thailand, Tree Physiol., 26, 643-656, 2006.

Jaffe, D., Prestbo, E., Swartzendruber, P., Weiss-Penzias, P., Kato, S., Takami, A., Hatakeyama, S., and Kajii, Y.: Export of atmospheric mercury from Asia, Atmos. Environ., 39, 3029-3038, 2005.

Kissinger, H. E.: Reaction Kinetics in Differential Thermal Analysis, J. Phys. Chem., 29, 1702-1706, doi:10.1021/ac60131a045, 1957.
Kuiken, T., Gustin, M., Zhang, H., Lindberg, S., and Sedinger, B.: Mercury emission from terrestrial background surfaces in the eastern USA. II: Air/surface exchange of mercury within forests from South Carolina to New England, Appl. Geochem., 23, 356368, 2008a.

Kuiken, T., Zhang, H., Gustin, M., and Lindberg, S.: Mercury emission from terrestrial background surfaces in the eastern USA. Part I: Air/surface exchange of mercury within a southeastern deciduous forest (Tennessee) over one year, Appl. Geochem., 23, 345-355, 2008b.

Laacouri, A., Nater, E. A., and Kolka, R. K.: Distribution and Uptake Dynamics of Mercury in Leaves of Common Deciduous Tree Species in Minnesota, USA, Environ. Sci. Technol., 47, 10462-10470, 2013.

Lalonde, J. D., Amyot, M., Doyon, M. R., and Auclair, J. C.: Photoinduced $\mathrm{Hg}(\mathrm{II})$ reduction in snow from the remote and temperate Experimental Lakes Area (Ontario, Canada), J. Geophys. Res.Atmos., 108, 4200, doi:10.1029/2001jd001534, 2003.

Lee, S. Z., Chang, L., Chen, C. M., Tsai, Y. I., and Liu, M. C.: Predicting soil-water partition coefficients for $\mathrm{Hg}$ (II) from soil properties, Water Sci. Technol., 43, 187-196, 2001.

Li, M., Xi, X. H., Xiao, G. Y., Cheng, H. X., Yang, Z. F., Zhou, G. H., Ye, J. Y., and Li, Z. H.: National multi-purpose regional geochemical survey in China, J. Geochem. Explor., 139, 21-30, 2014.

Lin, C. J., Lindberg, S. E., Ho, T. C., and Jang, C.: Development of a processor in BEIS3 for estimating vegetative mercury emission in the continental United States, Atmos. Environ., 39, 7529$7540,2005$.

Lin, C.-J., Gustin, M. S., Singhasuk, P., Eckley, C., and Miller, M.: Empirical Models for Estimating Mercury Flux from Soils, Environ. Sci. Technol., 44, 8522-8528, 10.1021/es1021735, 2010a.

Lin, C.-J., Pan, L., Streets, D. G., Shetty, S. K., Jang, C., Feng, X., Chu, H.-W., and Ho, T. C.: Estimating mercury emission outflow from East Asia using CMAQ-Hg, Atmos. Chem. Phys., 10, 1853-1864, doi:10.5194/acp-10-1853-2010, 2010 b.

Lin, C. J., Zhu, W., Li, X. C., Feng, X. B., Sommar, J., and Shang, L. H.: Novel Dynamic Flux Chamber for Measuring Air-Surface Exchange of Hg-o from Soils, Environ. Sci. Technol., 46, 89108920, doi:10.1021/Es3012386, 2012.

Lindberg, S. E., Zhang, H., Gustin, M., Vette, A., Marsik, F., Owens, J., Casimir, A., Ebinghaus, R., Edwards, G., Fitzgerald, C., Kemp, J., Kock, H. H., London, J., Majewski, M., Poissant, L., Pilote, M., Rasmussen, P., Schaedlich, F., Schneeberger, D., Sommar, J., Turner, R., Wallschlager, D., and Xiao, Z.: Increases in mercury emissions from desert soils in response to rainfall and irrigation, J. Geophys. Res.-Atmos., 104, 21879-21888, 1999.

Lindberg, S. E., Dong, W. J., and Meyers, T.: Transpiration of gaseous elemental mercury through vegetation in a subtropical wetland in Florida, Atmos. Environ., 36, 5207-5219, 2002.

Lindberg, S. E., Bullock, R., Ebinghaus, R., Engstrom, D., Feng, X. B., Fitzgerald, W., Pirrone, N., Prestbo, E., and Seigneur, C.: A synthesis of progress and uncertainties in attributing the sources of mercury in deposition, Ambio, 36, 19-32, 2007.

Liu, L., Xu, X. L., Zhuang, D. F., Chen, X., and Li, S.: Changes in the Potential Multiple Cropping System in Response to Climate Change in China from 1960-2010, Plos One, 8, 12, doi:10.1371/journal.pone.0080990, 2013. 
Liu, Y. B., Ju, W. M., Chen, J. M., Zhu, G. L., Xing, B. L., Zhu, J. F., and He, M. Z.: Spatial and temporal variations of forest LAI in China during 2000-2010, Chinese Sci. Bull., 57, 2846-2856, 2012.

Lyon, B. F., Ambrose, R., Rice, G., and Maxwell, C. J.: Calculation of soil-water and benthic sediment partition coefficients for mercury, Chemosphere, 35, 791-808, 1997.

Ma, M., Wang, D. Y., Du, H. X., Zheng, Z., and Wei, S. Q.: Atmospheric mercury deposition and its contribution of the regional atmospheric transport to mercury pollution at a national forest nature reserve, southwest China, Environ. Sci. Pollut. R, 22, 20007-20018, doi:10.1007/s11356-015-5152-9, 2015.

Mann, E. A., Mallory, M. L., Ziegler, S. E., Avery, T. S., Tordon, R., and O'Driscoll, N. J.: Photoreducible Mercury Loss from Arctic Snow Is Influenced by Temperature and Snow Age, Environ. Sci. Technol., 49, 12120-12126, 2015.

Mauclair, C., Layshock, J., and Carpi, A.: Quantifying the effect of humic matter on the emission of mercury from artificial soil surfaces, Appl. Geochem., 23, 594-601, 2008.

Maxwell, J. A., Holsen, T. M., and Mondal, S.: Gaseous Elemental Mercury (GEM) Emissions from Snow Surfaces in Northern New York, Plos One, 8, 7, doi:10.1371/journal.pone.0069342, 2013.

Moan, J.: 7 Visible Light and UV Radiation, Radiation, 69, 85-102, 2001.

Moore, C. and Carpi, A.: Mechanisms of the emission of mercury from soil: Role of UV radiation, J. Geophys. Res.-Atmos., 110, D24302, doi:10.1029/2004JD005567, 2005.

Moore, C. W. and Castro, M. S.: Investigation of factors affecting gaseous mercury concentrations in soils, Sci. Total Environ., 419, 136-143, 2012.

O’Driscoll, N. J., Siciliano, S. D., Lean, D. R. S., and Amyot, M.: Gross photoreduction kinetics of mercury in temperate freshwater lakes and rivers: Application to a general model of DGM dynamics, Environ. Sci. Technol., 40, 837-843, 2006.

Obrist, D., Pokharel, A. K., and Moore, C.: Vertical Profile Measurements of Soil Air Suggest Immobilization of Gaseous Elemental Mercury in Mineral Soil, Environ. Sci. Technol., 48, 2242-2252, 2014.

Pacyna, J. M., Travnikov, O., De Simone, F., Hedgecock, I. M., Sundseth, K., Pacyna, E. G., Steenhuisen, F., Pirrone, N., Munthe, J., and Kindbom, K.: Current and future levels of mercury atmospheric pollution on global scale, Atmos. Chem. Phys. Discuss., doi:10.5194/acp-2016-370, in review, 2016.

Pannu, R.: QUANTIFYING MERCURY REDUCTION KINETICS IN SOILS, Degree of Doctor of Philosophy, Department of Soil Science, University of Saskatchewan, 156 pp., 2012.

Pannu, R., Siciliano, S. D., and O'Driscoll, N. J.: Quantifying the effects of soil temperature, moisture and sterilization on elemental mercury formation in boreal soils, Environ. Pollut., 193, 138146, 2014.

Pirrone, N., Cinnirella, S., Feng, X., Finkelman, R. B., Friedli, H. R., Leaner, J., Mason, R., Mukherjee, A. B., Stracher, G. B., Streets, D. G., and Telmer, K.: Global mercury emissions to the atmosphere from anthropogenic and natural sources, Atmos. Chem. Phys., 10, 5951-5964, doi:10.5194/acp-10-59512010, 2010.

Poissant, L., Pilote, M., Yumvihoze, E., and Lean, D.: Mercury concentrations and foliage/atmosphere fluxes in a maple forest ecosystem in Quebec, Canada, J. Geophys. Res.-Atmos., 113, D10307, doi:10.1029/2007jd009510, 2008.

Quinones, J. L. and Carpi, A.: An Investigation of the Kinetic Processes Influencing Mercury Emissions from Sand and Soil Samples of Varying Thickness, J. Environ. Qual., 40, 647-652, doi:10.2134/jeq2010.0327, 2011.

Qureshi, A., O’Driscoll, N. J., MacLeod, M., Neuhold, Y. M., and Hungerbuhler, K.: Photoreactions of Mercury in Surface Ocean Water: Gross Reaction Kinetics and Possible Pathways, Environ. Sci. Technol., 44, 644-649, 2010.

Qureshi, A., MacLeod, M., and Hungerbuhler, K.: Quantifying uncertainties in the global mass balance of mercury, Global Biogeochem. Cy., 25, GB4012, doi:10.1029/2011gb004068, 2011.

Ran, Y. H., Li, X., Lu, L., and Li, Z. Y.: Large-scale land cover mapping with the integration of multi-source information based on the Dempster-Shafer theory, Int. J. Geogr. Inf. Sci., 26, 169191, 2012.

Risch, M. R., DeWild, J. F., Krabbenhoft, D. P., Kolka, R. K., and Zhang, L. M.: Litterfall mercury dry deposition in the eastern USA, Environ. Pollut., 161, 284-290, 2012.

Sauve, S., Hendershot, W., and Allen, H. E.: Solid-solution partitioning of metals in contaminated soils: Dependence on $\mathrm{pH}$, total metal burden, and organic matter, Environ. Sci. Technol., 34, 1125-1131, 2000.

Scholtz, M. T., Van Heyst, B. J., and Schroeder, W.: Modelling of mercury emissions from background soils, Sci. Total Environ., 304, 185-207, doi:10.1016/s0048-9697(02)00568-5, 2003.

Selin, N. E.: Global Biogeochemical Cycling of Mercury: A Review, Annu. Rev. Env. Resour., 34, 43-63, 2009.

Selin, N. E., Jacob, D. J., Yantosca, R. M., Strode, S., Jaegle, L., and Sunderland, E. M.: Global 3-D land-ocean-atmosphere model for mercury: Present-day versus preindustrial cycles and anthropogenic enrichment factors for deposition, Global Biogeochem. Cy., 22, GB3099, doi:10.1029/2007GB003040, 2008.

Shangguan, W., Dai, Y., Liu, B., Zhu, A., Duan, Q., Wu, L., Ji, D., Ye, A., Yuan, H., Zhang, Q., Chen, D., Chen, M., Chu, J., Dou, Y., Guo, J., Li, H., Li, J., Liang, L., Liang, X., Liu, H., Liu, S., Miao, C., and Zhang, Y.: A China data set of soil properties for land surface modeling, J. Adv. Model Earth Sy., 5, 212-224, doi:10.1002/jame.20026, 2013.

Shetty, S. K., Lin, C. J., Streets, D. G., and Jang, C.: Model estimate of mercury emission from natural sources in East Asia, Atmos. Environ., 42, 8674-8685, 2008.

Si, L. and Ariya, P. A.: Aqueous photoreduction of oxidized mercury species in presence of selected alkanethiols, Chemosphere, 84, 1079-1084, 2011.

$\mathrm{Si}$, L. and Ariya, P. A.: Photochemical reactions of divalent mercury with thioglycolic acid: Formation of mercuric sulfide particles, Chemosphere, 119, 467-472, 2015.

Smith-Downey, N. V., Sunderland, E. M., and Jacob, D. J.: Anthropogenic impacts on global storage and emissions of mercury from terrestrial soils: Insights from a new global model, J. Geophys. Res.-Biogeo., 115, G03008, doi:10.1029/2009jg001124, 2010.

Sobrado, M. A.: Cost-Benefit Relationships in Deciduous and Evergreen Leaves of Tropical Dry Forest Species, Funct. Ecol., 5, 608-616, 1991.

Sommar, J., Zhu, W., Lin, C. J., and Feng, X. B.: Field Approaches to Measure Hg Exchange Between Natural Surfaces and the At- 
mosphere A Review, Crit. Rev. Environ. Sci. Technol., 43, 16571739, doi:10.1080/10643389.2012.671733, $2013 \mathrm{a}$.

Sommar, J., Zhu, W., Shang, L. H., Feng, X. B., and Lin, C. J.: A whole-air relaxed eddy accumulation measurement system for sampling vertical vapour exchange of elemental mercury, Tellus B, 65, 98-110, doi:10.3402/tellusb.v65i0.19940, 2013 b.

Sommar, J., Zhu, W., Shang, L., Lin, C.-J., and Feng, X.: Seasonal variations in metallic mercury $\left(\mathrm{Hg}^{0}\right)$ vapor exchange over biannual wheat-corn rotation cropland in the North China Plain, Biogeosciences, 13, 2029-2049, doi:10.5194/bg-13-2029-2016, 2016a.

Sommar, J., Zhu, W., Shang, L., Lin, C.-J., and Feng, X.: Seasonal variations in metallic mercury $\left(\mathrm{Hg}^{0}\right)$ vapor exchange over biannual wheat-corn rotation cropland in the North China Plain, Biogeosciences, 13, 2029-2049, doi:10.5194/bg-13-2029-2016, 2016b.

Song, S., Selin, N. E., Soerensen, A. L., Angot, H., Artz, R., Brooks, S., Brunke, E.-G., Conley, G., Dommergue, A., Ebinghaus, R., Holsen, T. M., Jaffe, D. A., Kang, S., Kelley, P., Luke, W. T., Magand, O., Marumoto, K., Pfaffhuber, K. A., Ren, X., Sheu, G.-R., Slemr, F., Warneke, T., Weigelt, A., Weiss-Penzias, P., Wip, D. C., and Zhang, Q.: Top-down constraints on atmospheric mercury emissions and implications for global biogeochemical cycling, Atmos. Chem. Phys., 15, 7103-7125, doi:10.5194/acp-157103-2015, 2015.

Streets, D. G., Zhang, Q., and Wu, Y.: Projections of Global Mercury Emissions in 2050, Environ. Sci. Technol., 43, 2983-2988, 2009.

Streets, D. G., Devane, M. K., Lu, Z. F., Bond, T. C., Sunderland, E. M., and Jacob, D. J.: All-Time Releases of Mercury to the Atmosphere from Human Activities, Environ. Sci. Technol., 45, 10485-10491, 2011.

Strode, S. A., Jaegle, L., Jaffe, D. A., Swartzendruber, P. C., Selin, N. E., Holmes, C., and Yantosca, R. M.: Trans-Pacific transport of mercury, J. Geophys. Res.-Atmos., 113, D15305, doi:10.1029/2007JD009428, 2008.

Wang, D. Y., He, L., Shi, X. J., Wei, S. Q., and Feng, X. B.: Release flux of mercury from different environmental surfaces in Chongqing, China, Chemosphere, 64, 1845-1854, 2006.

Wang, R. L., Yu, G. R., He, N. P., Wang, Q. F., Zhao, N., Xu, Z. W., and Ge, J. P.: Latitudinal variation of leaf stomatal traits from species to community level in forests: linkage with ecosystem productivity, Sci Rep-Uk, 5, 14454, doi:10.1038/srep14454, 2015.

Wang, S., Zhang, L., Wang, L., Wu, Q., Wang, F., and Hao, J.: A review of atmospheric mercury emissions, pollution and control in China, Frontiers of Environ. Sci. Eng., 8, 631-649, doi:10.1007/s11783-014-0673-x, 2014.

Wang, S. F., Feng, X. B., Qiu, G. L., Wei, Z. Q., and Xiao, T. F.: Mercury emission to atmosphere from Lanmuchang $\mathrm{Hg}$ - $\mathrm{Tl}$ mining area, Southwestern Guizhou, China, Atmos. Environ., 39, 7459-7473, 2005.

Wang, X., Lin, C.-J., and Feng, X.: Sensitivity analysis of an updated bidirectional air-surface exchange model for elemental mercury vapor, Atmos. Chem. Phys., 14, 6273-6287, doi:10.5194/acp-14-6273-2014, 2014.

Wang, Z. W., Zhang, X. S., Xiao, J. S., Zhijia, C., and Yu, P. Z.: Mercury fluxes and pools in three subtropical forested catchments, southwest China, Environ. Pollut., 157, 801-808, 2009.
Wright, L. P. and Zhang, L. M.: An approach estimating bidirectional air-surface exchange for gaseous elemental mercury at AMNet sites, J. Adv. Model Earth Sy., 7, 35-49, 2015.

Xu, X. H., Yang, X. S., Miller, D. R., Helble, J. J., and Carley, R. J.: Formulation of bi-directional atmosphere-surface exchanges of elemental mercury, Atmos. Environ., 33, 4345-4355, doi:10.1016/S1352-2310(99)00245-9, 1999.

Yin, R., Feng, X., and Meng, B.: Stable Hg Isotope Variation in Rice Plants (Oryza sativa L.) from the Wanshan Hg Mining District, SW China, Environ. Sci. Technol., 47, 2238-2245, doi:10.1021/es304302a, 2013.

Yuan, H., Dai, Y. J., Xiao, Z. Q., Ji, D. Y., and Shangguan, W.: Reprocessing the MODIS Leaf Area Index products for land surface and climate modelling, Remote Sens. Environ., 115, 1171-1187, 2011.

Zhang, H. and Lindberg, S. E.: Processes influencing the emission of mercury from soils: A conceptual model, J. Geophys. Res.Atmos., 104, 21889-21896, 1999.

Zhang, H., Lindberg, S. E., and Gustin, M. S.: Nature of diel trend of mercury emission from soil: Current understanding and hypotheses, Abstr. Pap. Am. Chem. S, 222, U429-U429, 2001.

Zhang, L., Brook, J. R., and Vet, R.: A revised parameterization for gaseous dry deposition in air-quality models, Atmos. Chem. Phys., 3, 2067-2082, doi:10.5194/acp-3-2067-2003, 2003.

Zhang, L., Blanchard, P., Gay, D. A., Prestbo, E. M., Risch, M. R., Johnson, D., Narayan, J., Zsolway, R., Holsen, T. M., Miller, E. K., Castro, M. S., Graydon, J. A., Louis, V. L. St., and Dalziel, J.: Estimation of speciated and total mercury dry deposition at monitoring locations in eastern and central North America, Atmos. Chem. Phys., 12, 4327-4340, doi:10.5194/acp-12-43272012, 2012a.

Zhang, L., Blanchard, P., Johnson, D., Dastoor, A., Ryzhkov, A., Lin, C. J., Vijayaraghavan, K., Gay, D., Holsen, T. M., Huang, J., Graydon, J. A., St Louis, V. L., Castro, M. S., Miller, E. K., Marsik, F., Lu, J., Poissant, L., Pilote, M., and Zhang, K. M.: Assessment of modeled mercury dry deposition over the Great Lakes region, Environ. Pollut., 161, 272-283, 2012 b.

Zhang, L., Wang, S. X., Wang, L., Wu, Y., Duan, L., Wu, Q. R., Wang, F. Y., Yang, M., Yang, H., Hao, J. M., and Liu, X.: Updated Emission Inventories for Speciated Atmospheric Mercury from Anthropogenic Sources in China, Environ. Sci. Technol., 49, 3185-3194, 2015.

Zhang, L. X., Hu, Z. M., Fan, J. W., Zhou, D. C., and Tang, F. P.: A meta-analysis of the canopy light extinction coefficient in terrestrial ecosystems, Front. Earth Sci., 8, 599-609, 2014.

Zhang, Y., Jacob, D. J., Horowitz, H. M., Chen, L., Amos, H. M., Krabbenhoft, D. P., Slemr, F., St. Louis, V. L., and Sunderland, E. M.: Observed decrease in atmospheric mercury explained by global decline in anthropogenic emissions, P. Natl. Acad. Sci., 113, 526-531, doi:10.1073/pnas.1516312113, 2016.

Zhu, J., Wang, D., Liu, X., and Zhang, Y.: Mercury fluxes from air/surface interfaces in paddy field and dry land, Appl. Geochem., 26, 249-255, doi:10.1016/j.apgeochem.2010.11.025, 2011.

Zhu, J., Wang, T., Bieser, J., and Matthias, V.: Source attribution and process analysis for atmospheric mercury in eastern China simulated by CMAQ-Hg, Atmos. Chem. Phys., 15, 8767-8779, doi:10.5194/acp-15-8767-2015, 2015. 
Zhu, J. S., Wang, D. Y., and Ma, M.: Mercury release flux and its influencing factors at the air-water interface in paddy field in Chongqing, China, Chinese Sci. Bull., 58, 266-274, 2013.

Zhu, W.: Deployment and Evaluation of Enclosure and Micrometeorological Techniques for Quantifying Air-surface Exchange of Gaseous Elemental Mercury over Agricultural Lands, Doctor of Natural Science, University of Chinese Academy of Sciences, University of Chinese Academy of Sciences, 169 pp., 2014.

Zhu, W., Sommar, J., Lin, C.-J., and Feng, X.: Mercury vapor air-surface exchange measured by collocated micrometeorological and enclosure methods - Part I: Data comparability and method characteristics, Atmos. Chem. Phys., 15, 685-702, doi:10.5194/acp-15-685-2015, 2015a.
Zhu, W., Sommar, J., Lin, C.-J., and Feng, X.: Mercury vapor airsurface exchange measured by collocated micrometeorological and enclosure methods - Part II: Bias and uncertainty analysis, Atmos. Chem. Phys., 15, 5359-5376, doi:10.5194/acp-15-53592015, 2015b.

Zhu, W., Lin, C.-J., Wang, X., Sommar, J., Fu, X., and Feng, X.: Global observations and modeling of atmosphere-surface exchange of elemental mercury: a critical review, Atmos. Chem. Phys., 16, 4451-4480, doi:10.5194/acp-16-4451-2016, 2016. 